\title{
ע Koronapandemian ja sen rajoittamistoimien vaikutukset toimintarajoitteisten ihmisten elämään
}

Systemaattisesti kerättyä tietoa siitä, miten epidemian torjunta- ja rajoitustoimet vaikuttavat toimintarajoitteisten ihmisten elämään on saatavilla niukasti. Tässä tutkimuksessa kuvaamme näitä vaikutuksia toimintarajoitteisiin ihmisiin koko väestössä, ulkomaalaistaustaisessa väestössä sekä henkilökohtaista apua saavien vammaisten ihmisten ryhmässä.

Tutkimus perustuu kolmeen tuoreeseen Terveyden ja hyvinvoinnin laitoksen keräämään väestöä edustavaan aineistoon: FinSote 2020 -tutkimukseen, FinTerveys 2017 -seurantatutkimukseen sekä ulkomaalaistaustaisen väestön osalta MigCOVID-tutkimukseen. Lisäksi käytettiin henkilökohtaista apua saavien vaikeavammaisten ihmisten tutkimusta. Tutkittavat vastasivat koronapandemian vaikutuksia koskeviin kyselyihin vuoden 2020 viimeisinä tai vuoden 2021 ensimmäisinä kuukausina. Analyyseissä verrattiin toimintarajoitteisten ihmisten tilannetta muuhun väestöön. Tulokset esitetään ikäryhmittäin mallivakioituina prevalensseina perustuen logistisiin regressioanalyyseihin.

Toimintarajoitteiset ihmiset kokivat muuta väestöä yleisemmin yksinäisyyden ja univaikeuksien lisääntyneen koronaepidemian aikana. He myös raportoivat taloudellisen tilanteensa heikentyneen useammin kuin muut. Huolet tartunnan saamisesta sekä sosiaali- ja terveyspalveluiden riittämätön saanti olivat yleisempiä toimintarajoitteisilla kuin muilla. Monet epidemian epäsuotuisista vaikutuksista korostuivat ulkomailla syntyneillä toimintarajoitteisilla ja vaikeavammaisilla ihmisillä.

Koronaepidemia uhkaa lisätä toimintarajoitteisten ihmisten eriarvoisuutta. Epidemia on osoittanut, että toimintarajoitteisten ihmisten oikeudet ja tarpeet on otettava paremmin huomioon vastaavanlaisissa kriisitilanteissa. Luotettavaan tietoon perustuvat toimintaohjeet auttaisivat kuntia yhdenvertaisuuden edistämisessä.

ASIASANAT: Toimintarajoitteet, koronaepidemia, ulkomaalaistausta, yhdenvertaisuus

PÄIVI SAINIO, MARJA HOLM, JONNA IKONEN, MARIKA KORHONEN, PÄIVI NURMI-KOIKKALAINEN, SUVI PARIKKA, NATALIA SKOGBERG, ANNA VÄRE, PÄIVIKKI KOPONEN, SEPPO KOSKINEN

\section{YDINASIAT}

- Tietoa toimintarajoitteisten ihmisten selviämisestä koronaepidemiassa on niukasti. Tutkimuksemme kuvaa monipuolisesti koronaepidemian rajoitustoimien vaikutuksia heihin.

- Yksinäisyys, univaikeudet, huolet tartunnasta ja palveluiden saannista sekä heikentynyt taloudellinen tilanne korostuivat toimintarajoitteisten ihmisten arjessa.

- Luotettavaan tietoon perustuvat toimintaohjeet auttaisivat kuntia yhdenvertaisuuden edistämisessä.

\section{JOHDANTO}

Koronapandemia ja sen rajoittamistoimet ovat vaikuttaneet ihmisten elämään kaikkialla vuoden 2020 alkupuolelta asti (1). Rajoitteet ovat kohdistuneet ja vaikuttaneet väestöryhmiin eri tavoin. Vaarana on eriarvoisuuden syventyminen $(2,3)$. Hyvä toimintakyky antaa paremmat mahdollisuudet toimia myös poikkeusoloissa, kun taas erilaiset toimintarajoitteet voivat tuoda monenlaisia lisähaasteita rajoitustoimien muuttaessa tavanomaista arkea ja heikentäessä tukitoimien saata- 
vuutta. Erityisesti palvelujen saannin keskeytyminen tai epävarmuus välttämättömistä palveluista ovat herättäneet paljon huolta toimintarajoitteisten ihmisten keskuudessa (4). Kansainväliset järjestöt ovatkin tähdentäneet, että pandemian aikana tulisi erityisesti huolehtia toimintarajoitteisten ihmisten oikeuksien toteutumisesta yhdenvertaisesti muiden kanssa $(5,6)$.

Toimintarajoitteisia ihmisiä arvellaan maailmanlaajuisesti olevan 15 prosenttia väestöstä eli noin miljardi henkilöä (7). Suomessa heidän määräkseen on arvioitu lähes puoli miljoonaa, mutta määrä ja väestöosuus riippuvat käytetystä määritelmästä $(8,9)$. Määritelmät vaihtelevat, sillä toimintarajoitteisuus (disability) on monimutkainen, moniulotteinen ja dynaaminen käsite (7). Toimintarajoitteisuus syntyy ihmisen, hänen terveydentilansa sekä ympäristö- ja yksilötekijöiden dynaamisessa vuorovaikutuksessa (10). Suomen kielessä termi "disability" kääntyy sekä vammaisuudeksi että toimintarajoitteisuudeksi, ja kontekstista riippuen näillä käsitteillä tarkoitetaan toisinaan samaa, toisinaan osittain eri asiaa (11, 12). Esimerkiksi YK:n vammaissopimuksen (Convention on the rights of persons with disabilities) (13) määritelmän mukaan "vammaisiin henkilöihin kuuluvat ne, joilla on sellainen pitkäaikainen ruumiillinen, henkinen, älyllinen tai aisteibin liittyvä vamma, joka vuorovaikutuksessa erilaisten esteiden kanssa voi estää heidän täysimääräisen ja tehokkaan osallistumisensa ybteiskuntaan yhdenvertaisesti muiden kanssa." Vammaissopimuksen toimeenpanon seuranta edellyttää tilastotiedon keräämistä vammaisista tai toimintarajoitteisista ihmisistä, jolloin kohderyhmän määrittely on operationalisoitava mahdollisimman luotettavalla tavalla. Koko väestöä edustavissa kyselytutkimuksissa tämä on mahdollista käyttämällä YK:n tilastokomitean alaisen Washington Group on Disability Statistics -ryhmän kysymyssarjoja (14). Kohderyhmä voidaan määritellä myös vammaisuuteen liittyvien palveluiden tai etuuksien saamisena. Käytämme tässä artikkelissa näitä kahta tapaa, kun kuvaamme koronaepidemian vaikutuksia toimintarajoitteisten ja vammaisten ihmisten ryhmässä.

Toimintarajoitteisuus voi ilman pandemiasta johtuvia lisärasitteitakin aiheuttaa runsaasti haasteita arjessa ja hyvinvoinnissa (15). Toimintarajoitteisilla ihmisillä on keskimäärin muuta väestöä yleisemmin toimeentulovaikeuksia, ongelmia tarvitsemiensa terveyspalveluiden saannissa sekä osallistumisessa työelämään, opintoihin ja harrastuksiin. He kokevat myös muita useammin yksinäisyyttä ja sosiaalisten suhteiden vähyyttä. Heikompi elämänlaatu ja terveydentila sekä terveyden kannalta haitalliset elintavat ovat myös keskimäärin yleisempiä toimintarajoitteisten ryhmässä kuin muussa väestössä $(8,16-18$.

Osalla toimintarajoitteisista ihmisistä on sairauksia, jotka voivat altistaa koronavirustartunnalle tai lisätä taudin vakavuutta $(19,20)$. Kun terveyspalveluihin pääsy on jo lähtökohtaisesti vaikeutunut, voi pandemia entisestään heikentää heidän terveyttään. Iso-Britanniassa on havaittu, että koronavirustautiin liittyvät kuolemat ovat toimintarajoitteisilla ihmisillä yleisempiä kuin muussa väestössä. Epäedulliset sosioekonomiset (esim. heikompi koulutus, työtilanne ja tulot) ja elinoloihin liittyvät tekijät selittivät merkittävän osan kohonneesta kuolleisuusriskistä, mutta eivät kokonaan $(21,22$.)

Tässä tutkimuksessa tarkastelemme kolmea toimintarajoitteisten ihmisten ryhmää, jotka saattavat olla muuta väestöä haavoittuvammassa asemassa epidemian aikana. Ensinnäkin tarkastelemme toimintarajoitteisiksi tunnistettuja ihmisiä koko väestöä edustavassa aineistossa. Toimintarajoitteisiksi ihmisiksi määritellään siinä henkilöt, jotka kokevat huomattavia vaikeuksia perustoiminnoissa, kuten näkemisessä, kuulemisessa, kävelemisessä tai kognitiivisissa toiminnoissa (14). Kun heidän tilannettaan verrataan siihen väestönosaan, jolla näitä toimintarajoitteita ei ole, saadaan tietoa siitä, miten yhdenvertaisesti tai eriarvoisesti koronapandemian vaikutukset ovat kohdentuneet.

Toiseksi tarkastelemme toimintarajoitteisia henkilöitä ulkomailla syntyneiden väestöryhmässä. Ulkomaalaistaustaisilla ihmisillä on terveydessä, hyvinvoinnissa ja monilla muilla elämänalueilla keskimäärin enemmän haasteita kuin muulla väestöllä $(23,24)$. On myös viitteitä, että ulkomaalaistaustaiset ihmiset ovat olleet alttiimpia pandemian negatiivisille vaikutuksille (25). Suomessa ja monissa muissakin maissa koronavirustartuntoja todettiin ulkomaalaistaustaisen väestön keskuudessa selvästi enemmän kuin muussa väestössä (26). Taustalla vaikuttivat samat tekijät, jotka väestössä muutenkin lisäävät tartunnan todennäköisyyttä, esimerkiksi asuminen ahtaasti ja lähityö. Kun ulkomaalaistausta ja 
toimintarajoitteisuus risteävät, voi niiden yhteisvaikutus lisätä pandemiasta ja sen rajoittamistoimista aiheutuvia haittoja enemmän kuin kumpikaan riskitekijä yksinään $(27,28)$.

Kolmas kohderyhmämme on henkilökohtaista apua käyttävien vammaisten ryhmä. Henkilökohtaiseen apuun on oikeus vaikeavammaisilla henkilöillä, joka tarvitsevat pitkäaikaisen tai etenevän vamman tai sairauden johdosta välttämättä ja toistuvasti toisen henkilön apua suoriutuakseen tavanomaisista elämän toiminnoista eikä avun tarve johdu pääasiassa ikääntymiseen liittyvistä sairauksista ja toimintarajoitteista $(29,30)$. Heitä oli Suomen aikuisväestössä vuonna 2019 noin 26000 (31). Koronavirustartunnan riski voi heillä olla suurempi, koska he eivät voi täysin välttää sosiaalisia kontakteja (19). Henkilökohtaisen avun saajat tarvitsevat selviytymisensä tukena monia sellaisia palveluja, joiden tuottamista pandemia on vaikeuttanut (4).

Systemaattisesti kerättyä tietoa siitä, miten virus ja pandemian torjunta- ja rajoitustoimet vaikuttavat toimintarajoitteisiin ihmisiin on saatavilla melko niukasti. Luotettavan tiedon avulla voidaan havaita mahdolliset pandemian aiheuttamat yhdenvertaisuuden puutteet, suunnitella toimenpiteitä epäkohtien korjaamiseksi sekä seurata niiden vaikuttavuutta (32-34.)

Tämän tutkimuksen tarkoituksena luoda yleiskuva koronapandemian ja sen rajoittamistoimien vaikutuksista toimintarajoitteisten ihmisten elämään. Tutkimuskysymykset ovat:

1) Miten koronapandemia ja sen rajoitustoimet ovat vaikuttaneet toimintarajoitteisten ja muiden aikuisten psyykkiseen, sosiaaliseen ja taloudelliseen hyvinvointiin sekä sosiaali- ja terveyspalveluiden käyttöön)?

2) Poikkeavatko em. vaikutukset toisistaan työikäisillä ulkomailla syntyneillä ja koko väestössä?

3) Millaisia ongelmia koronapandemia ja sen rajoitustoimet ovat tuoneet henkilökohtaista apua käyttävien vammaisten ihmisten elämään?

\section{MENETELMÄT}

\section{AINEISTOT}

Tutkimuksessa käytettiin kolmea Terveyden ja hyvinvoinnin laitoksen (THL) keräämää väestötutkimusaineistoa, joissa kartoitettiin koronaepidemian ja sen rajoitustoimien vaikutuksia ihmisten elämään (Taulukko 1). Tulokset esitetään kahdessa ikäryhmässä, 21-66-vuotiaat (Taulukko 3) ja 67 vuotta täyttäneet (Taulukko 2). Työikäisiä koskevassa taulukossa esitetään vertailu ulkomailla syntyneiden aineistoon. Lisäksi kuviossa 1 esitetään tulokset koskien 21 vuotta täyttäneitä ja verrataan henkilökohtaista apua saavien ja koko väestön tuloksia.

Kansallisen terveys-, hyvinvointi- ja palvelututkimuksen FinSote 2020:n (FS) (35) aineisto kerättiin syyskuun 2020 ja helmikuun 2021 välisenä aikana (36). Kysely lähetettiin 61600 henkilön otokselle. Otantamenetelmänä käytettiin hyvinvointialueittain ositettua satunnaisotantaa, ja otoskoko oli 2800 henkilöä/hyvinvointialue. Vastaajajoukko on painottamalla korjattu vastaamaan perusjoukkoa eli 20 vuotta täyttänyttä Suomen väestöä. Kaikille yhteisten kysymysten lisäksi kyselylomakkeelle sisältyi 48400 henkilön alaotokselle osoitettuja kysymyksiä koronaepidemian koetuista vaikutuksista (koronamoduuli). Tässä tutkimuksessa rajaudutaan koronamoduulialaotoksen 21 vuotta täyttäneisiin $(\mathrm{n}=47$ 203), joista kyselyyn vastasi 22042 (osallistumisaktiivisuus $47 \%$ ). Kyselyyn oli mahdollisuus vastata sähköisesti tai paperilomakkeella. Niille, jotka eivät vastanneet ensimmäisen yhteydenoton jälkeen, lähetettiin postitse muistutus vastata paperilomakkeella tai netissä. Tutkimus on hyväksytty THL:n tutkimuseettisessä toimikunnassa.

FinTerveys 2017 -seurantatutkimus (FT) (37) on vuonna 2017 toteutetun aikuisväestöä edustavan terveystarkastustutkimuksen $(38,39)$ seurantakysely, jonka aineisto kerättiin marraskuun 2020 ja tammikuun 2021 välisenä aikana. FinTerveys 2017 -tutkimuksen otos poimittiin kaksivaiheisena ositettuna satunnaisotoksena. Seurantatutkimuksen kysely lähetettiin kaikille niille vuonna 2017 poimittuun otokseen kuuluneille $(\mathrm{n}=10305)$, jotka olivat elossa, asuivat edelleen Suomessa eivätkä olleet kieltäytyneet jatkoyhteydenotoista tai peruneet suostumustaan ( $\mathrm{n}=9580)$. Kyselyyn vastanneet olivat 21-vuotiaita tai van- 
hempia ( $\mathrm{n}=5400$, osallistumisaktiivisuus $56 \%$ ). Kyselyyn oli mahdollista vastata sähköisesti tai paperilomakkeella. Lisäksi puhelimitse tavoiteltiin niitä, jotka eivät olleet vastanneet muulla tavoin. Tutkimus on hyväksytty Helsingin ja Uudenmaan sairaanhoitopiirin eettisessä toimikunnassa.

Koronaepidemian vaikutukset ulkomailla syntyneiden hyvinvointiin -tutkimus (MigCOVIDtutkimus, MC) (40) on vuosina 2018-2019 toteutetun FinMonik-tutkimuksen (23) seurantakysely, joka lähetettiin kaikille FinMonik-tutkimukseen osallistuneille henkilöille sekä Somaliassa syntyneiden lisäotokselle. Otokseen kuuluvat olivat 20-66-vuotiaita ( $n=6139)$. FinMonik-otos perustui ositettuun satunnaisotantaan, joka koostui 18 maakunnasta ja kuudesta suurimmasta kaupungista (Helsinki, Espoo, Tampere, Vantaa, Oulu ja Turku). Somaliassa syntyneiden lisäotos perustui yksinkertaiseen satunnaisotantaan. MigCOVID-tutkimuksen kyselyaineisto kerättiin sähköisellä 18 kielelle käännetyllä lomakkeella lokakuun 2020 ja helmikuun 2021 välillä. Täydentävässä tiedonkeruussa tavoiteltiin tutkittavia postitse paperisella lomakkeella tai puhelimitse. Tässä tutkimuksessa rajauduttiin 21 vuotta täyttäneisiin ( $\mathrm{n}=6004)$, joista kyselyyn vastasi 3611 henkilöä (osallistumisaktiivisuus $60 \%$ ). Tutkimus on hyväksytty THL:n tutkimuseettisessä toimikunnassa.

Lisäksi käytettiin THL:ssä kerättyä kyselyaineistoa, jonka kohderyhmänä oli 18 vuotta täyttäneet henkilökohtaista apua käyttävät vammaiset henkilöt (HA) (41). Tiedonkeruu toteutettiin joulukuun 2020 ja tammikuun 2021 välillä. Kohderyhmää tavoiteltiin jakamalla linkkiä sähköiseen kyselyyn kuntien, vammaispalveluiden vastuuhenkilöiden ja vammaisneuvostojen sekä vammaisjärjestöjen ja Heta-liiton (henkilökohtaista apua saavien työnantajaliitto) kautta. Kyselyyn vastasi 1025 vähintään 18 -vuotiasta henkilöä, joille heidän asuinkuntansa oli myöntänyt henkilökohtaista apua (naisia $72 \%$ ). Tässä tutkimuksessa tarkasteltiin 21 vuotta täyttäneitä kyselyyn vastanneita henkilöitä $(n=1012)$. Tutkimuksen toteutus ei vaatinut eettisen toimikunnan käsittelyä.

\section{TOIMINTARAJOITTEISUUS}

Toimintarajoitteisuutta kartoitettiin kaikissa tutkimusaineistoissa kahdella kysymyksellä:

1. "Pystyttekö yleensä seuraaviin suorituksiin? a) kävelemään noin puolen kilometrin matkan levähtämättä, b) lukemaan tavallista sanomalehtitekstiä (silmälaseilla tai ilman) c) kuulemaan, mitä usean henkilön välisessä keskustelussa sanotaan (kuulokojeen kanssa tai ilman)”. Vastausvaihdot olivat 1) pystyn vaikeuksitta, 2) pystyn, mutta vaikeuksia on jonkin verran, 3) pystyn, mutta se on minulle erittäin vaikeaa tai 4 ) en pysty lainkaan.

2. "Millaiseksi koette muistinne? Muistini toimii..." Vastausvaihdot olivat 1) erittäin hyvin 2) hyvin 3) tyydyttävästi 4) huonosti tai 5) erittäin huonosti.

Toimintarajoitteisiksi henkilöiksi luokiteltiin ne, jotka valitsivat ensimmäisen kysymyksen yhdessä tai useammassa kohdassa vastausvaihtoehdon 3 tai 4, tai muistia koskevassa kysymyksessä vaihtoehdon 4 tai $5(14,42)$. Väestöä edustaviin aineistoihin (FS, FT, MC) perustuvissa tarkasteluissa vertailuryhmänä olivat ne henkilöt, joilla oli enintään lieviä toimintakyvyn vajeita.

\section{MUUTTUJAT}

Koronaepidemian vaikutuksista hyvinvointiin tiedusteltiin kaikissa tutkimuksissa, mutta kysymysten määrä vaihteli jonkin verran tutkimusten välillä. Jos kysymys oli sekä FS- että FT-tutkimuksissa, valittiin se koko väestöä koskeviin taulukoihin FS-tutkimuksesta suuremman osallistujamäärän takia. FT-tutkimuksesta otettiin mukaan sellaiset muuttujat, joita ei ollut FS-tutkimuksessa. Taulukoihin 2 ja 3 ja kuvioon 1 on merkitty, mihin tutkimukseen kutakin muuttujaa koskevat tulokset perustuvat.

\section{Arkielämä ja hyvinvointi}

Koronaepidemian vaikutuksia arkielämään ja hyvinvointiin selvitettiin tiedustelemalla, ovatko koronaepidemia tai sen rajoitustoimet vaikuttaneet yksinäisyyden tunteeseen, yhteydenpitoon ystäviin ja sukulaisiin, kerho- tai yhdistystoimintaan osallistumiseen, perheen sisäisiin erimielisyyksiin ja ristiriitoihin, univaikeuksiin ja painajaisuniin sekä toiveikkuuteen tulevaisuuden suhteen. Vastausvaihtoehtoja oli neljä: 1) ei vaikutusta, 2) kyllä, vähentynyt, 3) kyllä, lisääntynyt ja 4) ei koske 
minua. Tämän artikkelin analyyseissä tarkastellaan hyvinvoinnin kannalta negatiivisia muutoksia (esimerkiksi yksinäisyys on lisääntynyt, toiveikkuus tulevaisuuden suhteen on vähentynyt). $\mathrm{Ne}$, jotka vastasivat vaihtoehdon "ei koske minua" poistettiin analyysista.

Koronaviruksen aiheuttamia huolia selvitettiin kysymyksillä "Oletko ollut huolissasi koronavirustartunnan saamisesta?" ja " Oletko ollut huolissasi terveydenhuoltojärjestelmän kyvystä hoitaa kaikki koronaviruspotilaat?". Vastausvaihtoehtoja oli kolme: 1) en ollenkaan 2) vähän ja 3) paljon. Paljon huolia tartunnan saamisesta -muuttuja muodostettiin laskemalla vaihtoehdon 3 vastanneiden osuus kaikista vastaajista. Paljon huolia terveydenhuoltojärjestelmän kyvystä hoitaa kaikki koronaviruspotilaat -muuttuja muodostettiin samalla tavalla. MigCOVID-tutkimuksessa vastausvaihtoehtoja näihin kysymyksiin oli viisi: 1) en ollenkaan, 2) vähän, 3) kohtalaisesti, 4) melko paljon, 5) hyvin paljon. Paljon huolia -muuttujat muodostettiin yhdistämällä vaihtoehdot 4 ja 5 .

Taloudellista tilannetta kartoitettiin kysymyksellä: "Onko koronaepidemia heikentänyt taloudellista tilannettasi?" Vastausvaihtoehtoina olivat: 1) erittäin paljon, 2) melko paljon, 3) jonkin verran, 4) vähän ja 5) ei lainkaan. Vaihtoehdot 1 , 2 ja 3 luokiteltiin heikentyneeksi taloudelliseksi tilanteeksi.

\section{Terveyspalvelut}

Riittämätöntä terveyspalveluiden saantia kartoitettiin kysymyksellä: "Oletko mielestäsi saanut riittävästi seuraavia terveyspalveluita 12 viime kuukauden aikana: (a) lääkärin vastaanottopalvelut, (b) sairaanhoitajan tai terveydenhoitajan vastaanottopalvelut ja (c) hammaslääkäripalvelut”. Vastausvaihtoehtoja oli neljä: 1) en ole tarvinnut, 2) olisin tarvinnut, mutta en saanut, 3) olen käyttänyt, ei ollut riittävää ja 4) olen käyttänyt, oli riittävää. Näistä muodostettiin tyydyttymätöntä palvelutarvetta kuvaava muuttuja erikseen kullekin palvelulle laskemalla vaihtoehdon 2 tai 3 vastanneiden osuus palvelua tarvinneista (vaihtoehdot 2, 3 tai 4). MC- ja HA-kyselyissä pyydettiin arvioimaan palveluiden riittävyyttä vuoden 2020 maaliskuun alun jälkeen.

\section{Henkilökohtaisen avun kyselyn lisämuuttujat}

Henkilökohtaisen avun käyttäjien kyselyssä kar- toitettiin lisäksi fysioterapian riittämätöntä saantia samalla tavalla kuin edellä kuvattuja lääkärin, sairaanhoitajan tai hoitajan ja hammaslääkärin palvelujen riittämätöntä saantia. Riittämätöntä sosiaalipalveluiden saantia kartoitettiin henkilökohtaisen avun käyttäjiltä kysymyksellä: "Oletko mielestäsi saanut riittävästi seuraavia sosiaalipalveluita maaliskuun alun 2020 jälkeen: (a) henkilökohtainen apu, (b) sosiaalityöntekijän tai -ohjaajan palvelut”. Tyydyttymätöntä palvelutarvetta kuvaavat muuttujat muodostettiin samalla tavoin kuin terveyspalveluiden kohdalla. Lisäksi kartoitettiin henkilökohtaisen avun toteutukseen liittyviä ongelmia kysymyksellä: ”Onko henkilökohtaisen apusi toteutuksessa ollut ongelmia maaliskuun alun 2020 jälkeen?” (kyllä/ei). Myöntävästi vastanneilta kysyttiin ongelmista tarkemmin. Tässä tarkastellaan niiden osuutta, jotka ovat raportoineet, että avustajia ei ole ollut saatavilla, avustaja on ollut sairaana tai karanteenissa, tai että ei ole uskaltanut hankkia uutta avustajaa tai käyttää myönnettyjä tunteja koronaviruksen takia. Lisäksi ongelmia kokeneilta kysyttiin: "Onko henkilökohtaisen avun toteutuksessa ollut enemmän ongelmia koronaepidemian aikana kuin ennen sitä?” (kyllä/ei/sain avustajapäätöksen vasta maaliskuun jälkeen/en osaa sanoa).

\section{TILASTOLLISET MENETELMÄT}

FS-, FT- ja MC-väestöaineistot analysoitiin käyttäen SAS Enterprise Guide 7.1 ja STATA 16.1 -ohjelmistoja. Tutkimusten otanta-asetelmat ja vastauskato otettiin huomioon käyttämällä otantaasetelman ja painokertoimet huomioivaa komentoa (svyset, STATA) (43). Painokertoimet laskettiin Inverse probability weighting -menetelmällä (IPW) $(44,45)$ taustamuuttujien suhteen. Painokertoimien muodostamisessa käytettiin osin eri taustamuuttujia eri aineistoissa. Tutkimuskysymyksiin vastattiin seuraavilla menetelmillä eri aineistoissa.

1. Toimintarajoitteisten ihmisten kokemukset koronaepidemian vaikutuksista verrattuna muuhun väestöön, tutkimusaineistoina FS- ja FT-aineistot (Taulukot 2 ja 3). Toimintarajoitteisten ihmisten ja muun väestön väliset erot estimoitiin logistisella regressioanalyysilla, kun sukupuolen ja iän vaikutus oli kontrolloitu. Waldin testillä (46) estimoitiin tilastollista merkitsevyyttä ja rajana käytettiin p-arvoa 
$<0,05$. Ikä- ja sukupuolivakioidut esiintyvyysluvut laskettiin käyttäen logistiseen regressioanalyyseihin perustuvaa mallivakiointia (predictive margins) (47). Tuloksista esitetään mallivakioidut esiintyvyydet tutkimusryhmittäin ja $95 \%$ luottamusvälit (95\% LV).

2. Ulkomailla syntyneiden ja koko väestön väliset erot, tutkimusaineistoina MC-, FS- ja FT-aineistot (Taulukko 3). Jotta ulkomailla syntyneitä voitiin verrata koko väestöön, MC-aineisto yhdistettiin kumpaankin väestöaineistoon erikseen (48). Vertailtavien ryhmien erot estimoitiin samoilla menetelmillä kuin tutkimuskysymyksessä 1 . Tuloksista esitetään mallivakioidut esiintyvyydet tutkimusryhmittäin ja $95 \%$ luottamusvälit (95\% LV).

3. Vaikutukset henkilökohtaista apua saavien elämään, tutkimusaineistoina HA-, FS- ja FT-aineistot (Kuvio 1). Jotta HA aineistoa voitiin verrata muuhun väestöön, HA-aineisto yhdistettiin kumpaankin väestöaineistoon erikseen (48). Eroja tutkittiin henkilökohtais- ta apua saavien ja koko väestön välillä. Tulokset analysointiin samoilla menetelmillä kuin tutkimuskysymyksessä 1 . Tuloksista esitetään mallivakioidut esiintyvyydet tutkimusryhmittäin ja $95 \%$ luottamusvälit (95\% LV). Lisäksi määritettiin henkilökohtaisen avun kyselyn lisämuuttujien esiintyvyydet HA-aineistossa.

\section{TULOKSET}

\section{VAIKUTUKSET TOIMINTARAJOITTEISTEN IHMISTEN ARKIELÄMÄÄN, HYVINVOINTIIN SEKÄ SOSIAALI- JA TERVEYSPALVELUJEN KÄYTTÖÖN}

Toimintarajoitteisten osuus 20 vuotta täyttäneestä väestöstä oli noin 10 prosenttia. Osuus oli suurempi eläkeikäisessä väestössä (noin $23 \%$ ) kuin työikäisessä väestössä (noin $6 \%$ ). Ulkomailla syntyneessä työikäisessä väestössä toimintarajoitteisten osuus oli suurempi (noin $10 \%$ ) kuin koko työikäisessä väestössä. Rajoitteet toimintakyvyn eri ulottuvuuksissa yleistyvät selvästi iän myötä. (Taulukko 1.)

Taulukko 1. Vastaajien taustatiedot sekä toimintarajoitteiden yleisyys ikäryhmittäin väestöä edustavissa aineistoissa. Luvut ovat painotettuja.

\begin{tabular}{|c|c|c|c|c|c|c|c|}
\hline & \multirow{2}{*}{$\begin{array}{l}\text { FinSote } 2020 \\
(\mathrm{FS}) \\
21-66 \\
\mathrm{n}=10855 \\
\end{array}$} & \multirow[b]{2}{*}{$\begin{array}{l}67+ \\
\mathrm{n}=11187 \\
\end{array}$} & \multirow[b]{2}{*}{$\begin{array}{l}21+ \\
\mathrm{n}=22042\end{array}$} & \multicolumn{3}{|c|}{$\begin{array}{l}\text { FinTerveys } 2017 \text {-seurantatutkimus } \\
\text { (FT) }\end{array}$} & \multirow{2}{*}{$\begin{array}{l}\text { MigCovid } \\
\text { (MC) } \\
21-66 \\
n=3611\end{array}$} \\
\hline & & & & $\begin{array}{l}21-66 \\
\mathrm{n}=3490\end{array}$ & $\begin{array}{l}67+ \\
\mathrm{n}=1910 \\
\end{array}$ & $\begin{array}{l}21+ \\
\mathrm{n}=5400\end{array}$ & \\
\hline Naisia (\%) & 51,1 & 55,5 & 52,3 & 49,5 & 56,9 & 51,4 & 48,4 \\
\hline Ikä $(v)$, ka $(S E)^{1}$ & $\begin{array}{l}43,9 \\
(0,16)\end{array}$ & $\begin{array}{l}76,0 \\
(0,08)\end{array}$ & $\begin{array}{l}52,2 \\
(0,17)\end{array}$ & $\begin{array}{l}44,2 \\
(0,39)\end{array}$ & $\begin{array}{l}76,5 \\
(0,20)\end{array}$ & $\begin{array}{l}52,4 \\
(0,50)\end{array}$ & $\begin{array}{l}40,6 \\
(0,34)\end{array}$ \\
\hline $\begin{array}{l}\text { Toimintarajoit- } \\
\text { teisten osuus }{ }^{2} \\
(\%, 95 \% \mathrm{LV})^{3}\end{array}$ & $\begin{array}{l}6,7 \\
(6,1-7,3)\end{array}$ & $\begin{array}{l}25,3 \\
(24,3-26,2)\end{array}$ & $\begin{array}{l}11,5 \\
(11,0-12,0)\end{array}$ & $\begin{array}{l}5,5 \\
(4,7-6,3)\end{array}$ & $\begin{array}{l}22,2 \\
(19,9-24,5)\end{array}$ & $\begin{array}{l}9,7 \\
(8,8-10,6)\end{array}$ & $\begin{array}{l}10,2 \\
(8,3-12,0)\end{array}$ \\
\hline $\begin{array}{l}\text { Kävely- } \\
\text { vaikeudet }^{4}\end{array}$ & $\begin{array}{l}2,8 \\
(2,4-3,2)\end{array}$ & $\begin{array}{l}19,3 \\
(18,4-20,2)\end{array}$ & $\begin{array}{l}7,1 \\
(6,7-7,4)\end{array}$ & $\begin{array}{l}1,9 \\
(1,5-2,3)\end{array}$ & $\begin{array}{l}15,1 \\
(13,1-17,1)\end{array}$ & $\begin{array}{l}5,1 \\
(4,5-5,8)\end{array}$ & $\begin{array}{l}2,7 \\
(1,7-3,8)\end{array}$ \\
\hline $\begin{array}{l}\text { Näkö- } \\
\text { vaikeudet }{ }^{4}\end{array}$ & $\begin{array}{l}1,6 \\
(1,3-1,9)\end{array}$ & $\begin{array}{l}4,4 \\
(4,0-4,9)\end{array}$ & $\begin{array}{l}2,3 \\
(2,1-2,6)\end{array}$ & $\begin{array}{l}1,4 \\
(1,0-1,8)\end{array}$ & $\begin{array}{l}5,4 \\
(3,9-6,9)\end{array}$ & $\begin{array}{l}2,4 \\
(1,9-2,9)\end{array}$ & $\begin{array}{l}4,2 \\
(2,8-5,6)\end{array}$ \\
\hline $\begin{array}{l}\text { Kuulo- } \\
\text { vaikeudet }^{4}\end{array}$ & $\begin{array}{l}1,4 \\
(1,1-1,7)\end{array}$ & $\begin{array}{l}6,6 \\
(6,0-7,1)\end{array}$ & $\begin{array}{l}2,7 \\
(2,5-3,0)\end{array}$ & $\begin{array}{l}1,1 \\
(0,6-1,6)\end{array}$ & $\begin{array}{l}7,6 \\
(6,1-9,1)\end{array}$ & $\begin{array}{l}2,7 \\
(2,2-3,2)\end{array}$ & $\begin{array}{l}2,1 \\
(1,2-3,0)\end{array}$ \\
\hline Muisti-ongelmat ${ }^{5}$ & $\begin{array}{l}2,6 \\
(2,2-3,1)\end{array}$ & $\begin{array}{l}4,9 \\
(4,4-5,4)\end{array}$ & $\begin{array}{l}3,2 \\
(2,9-3,6)\end{array}$ & $\begin{array}{l}2,4 \\
(1,9-2,9)\end{array}$ & $\begin{array}{l}5,3 \\
(4,1-6,6)\end{array}$ & $\begin{array}{l}3,1 \\
(2,6-3,7)\end{array}$ & $\begin{array}{l}5,3 \\
(3,9-6,8)\end{array}$ \\
\hline
\end{tabular}

${ }^{1} \mathrm{SE}=$ keskivirhe

${ }^{2}$ Toimintarajoitteisiksi määriteltiin ne, joilla on suuria vaikeuksia puolen kilometrin kävelyssä, sanomalehtitekstin näkemisessä tai usean henkilön välisen keskustelun kuulemisessa ja ne, jotka eivät lainkaan suoriudu em. tehtävistä ja ne, jotka arvioivat muistinsa huonoksi tai erittäin huonoksi

$395 \%$ LV $=95 \%$ luottamusväli

${ }^{4} \mathrm{Oma}$ arvio: suuria vaikeuksia tai ei pysty

${ }^{5} \mathrm{Oma}$ arvio: huono tai erittäin huono 
Toimintarajoitteiset ihmiset kokivat monissa asioissa muuta väestöä yleisemmin koronaepidemian negatiivisia vaikutuksia arkielämäänsä ja hyvinvointiinsa. Useimmiten erot näkyivät sekä eläkeikäisillä (Taulukko 2) että työikäisillä (Taulukko 3). Noin 44 prosenttia eläkeikäisistä ja 46 prosenttia työikäisistä toimintarajoitteisista ihmisistä koki, että yksinäisyys oli lisääntynyt, kun muusta väestöstä koki näin noin kolmannes. Nuoremmassa ikäryhmässä kerho- ja yhdistystoimintaan osallistumista oli vähentänyt noin puolet sekä toimintarajoitteisista että muista ihmisistä, mutta yhteydenpito ystäviin ja sukulaisiin oli vähentynyt hieman harvemmalla toimintarajoitteisten kuin muiden ihmisten ryhmässä (Taulukko 3). Vanhemmassa ikäryhmässä runsaat 60 prosenttia sekä toimintarajoitteisista että muista ihmisistä oli vähentänyt näitä sosiaalisen aktiivisuuden muotoja (Taulukko 2).

Perheen sisäisten erimielisyyksien ja ristiriitojen lisääntyminen oli vanhemmassa ikäryhmässä yleisempää toimintarajoitteisten henkilöiden keskuudessa kuin muussa väestössä, mutta työikäisillä eroa ei ollut. Molemmissa ikäryhmissä noin neljännes toimintarajoitteisista ihmisistä, mutta vain noin joka kymmenes muista ihmisistä, koki painajaisunien tai univaikeuksien lisääntyneen. Myös toiveikkuus tulevaisuuden suhteen oli toimintarajoitteisten keskuudessa vähentynyt yleisemmin, ja he raportoivat useammin myös taloudellisen tilanteensa heikentyneen. Noin neljännes toimintarajoitteisista ihmisistä sekä työ- että eläkeiässä oli erittäin huolissaan tartunnan saamisesta, muusta väestöstä 16 prosenttia (työikäiset) ja 22 prosenttia (eläkeikäiset). Terveydenhuoltojärjestelmän kyvystä hoitaa kaikki potilaat oli erittäin huolissaan niin ikään suurempi osa toimintarajoitteisista työikäisistä (29\%) ja eläkeikäisistä $(26 \%)$ ihmisistä kuin muusta väestöstä (työikäiset $18 \%$ ja eläkeikäiset $20 \%$ ).

Taulukko 2. Koronaepidemian koetut vaikutukset 67 vuotta täyttäneisiin toimintarajoitteisiin ja muihin ihmisiin. Ikä- ja sukupuolivakioitu.

\begin{tabular}{|c|c|c|c|}
\hline & $\begin{array}{l}\text { Toimintarajoitteiset } \\
\%(95 \% \mathrm{LV})^{3}\end{array}$ & $\begin{array}{l}\text { Muu väestö } \\
\%(95 \% \mathrm{LV})\end{array}$ & $\mathrm{p}^{4}$ \\
\hline $\begin{array}{l}\text { Arkielämä ja hyvinvointi } \\
\text { Yksinäisyys lisääntynyt }^{1}\end{array}$ & $\begin{array}{l}44,0 \\
(41,4-46,6)\end{array}$ & $\begin{array}{l}31,8 \\
(30,4-33,2)\end{array}$ & $<, 001$ \\
\hline Yhteydenpito ystäviin ja sukulaisiin vähentynyt ${ }^{1}$ & $\begin{array}{l}62,6 \\
(60,1-65,0)\end{array}$ & $\begin{array}{l}64,3 \\
(63,0-65,7)\end{array}$ & ns. \\
\hline $\begin{array}{l}\text { Kerho- tai yhdistystoimintaan osallistuminen } \\
\text { vähentynyt }{ }^{2}\end{array}$ & $\begin{array}{l}61,8 \\
(54,5-69,2)\end{array}$ & $\begin{array}{l}63,9 \\
(60,8-66,9)\end{array}$ & ns. \\
\hline $\begin{array}{l}\text { Perheen sisäiset erimielisyydet ja ristiriidat } \\
\text { lisääntyneet }{ }^{2}\end{array}$ & $\begin{array}{l}11,4 \\
(5,9-16,9)\end{array}$ & $\begin{array}{l}4,5 \\
(3,0-6,0)\end{array}$ & $<, 01$ \\
\hline Univaikeudet tai painajaisunet lisääntyneet ${ }^{1}$ & $\begin{array}{l}23,9 \\
(21,6-26,3)\end{array}$ & $\begin{array}{l}13,6 \\
(12,6-14,6)\end{array}$ & $<, 001$ \\
\hline Toiveikkuus tulevaisuuden suhteen vähentynyt ${ }^{1}$ & $\begin{array}{l}34,2 \\
(31,7-36,7)\end{array}$ & $\begin{array}{l}31,3 \\
(29,9-32,6)\end{array}$ & $<, 05$ \\
\hline Taloudellinen toimeentulo heikentynyt ${ }^{2}$ & $\begin{array}{l}16,5 \\
(11,5-21,6)\end{array}$ & $\begin{array}{l}7,1 \\
(5,8-8,5)\end{array}$ & $<, 001$ \\
\hline Paljon huolta tartunnan saamisesta ${ }^{1}$ & $\begin{array}{l}25,2 \\
(23,0-27,3)\end{array}$ & $\begin{array}{l}21,7 \\
(20,5-22,8)\end{array}$ & $<, 01$ \\
\hline 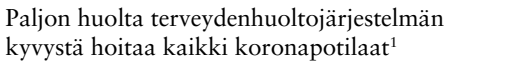 & $\begin{array}{l}26,3 \\
(24,1-28,5)\end{array}$ & $\begin{array}{l}19,9 \\
(18,8-21,0)\end{array}$ & $<, 001$ \\
\hline \multicolumn{4}{|l|}{ Terveyspalvelut } \\
\hline $\begin{array}{l}\text { Tyydyttämätön lääkärin vastaanottopalvelun } \\
\text { tarve }^{1}\end{array}$ & $\begin{array}{l}29,4 \\
(27,0-31,8)\end{array}$ & $\begin{array}{l}17,2 \\
(16,1-18,4)\end{array}$ & $<, 001$ \\
\hline $\begin{array}{l}\text { Tyydyttämätön hoitajan vastaanottopalvelun } \\
\text { tarve }^{1}\end{array}$ & $\begin{array}{l}21,3 \\
(19,0-23,7)\end{array}$ & $\begin{array}{l}12,2 \\
(11,1-13,3)\end{array}$ & $<, 001$ \\
\hline Tyydyttämätön hammaslääkäripalvelun tarve ${ }^{1}$ & $\begin{array}{l}25,6 \\
(22,6-28,6)\end{array}$ & $\begin{array}{l}17,3 \\
(16,0-18,6)\end{array}$ & $<, 001$ \\
\hline
\end{tabular}

${ }^{1}$ Tulos perustuu FinSote 2020 -aineistoon

${ }^{2}$ Tulos perustuu FinTerveys 2017 -seurantatutkimuksen aineistoon

$395 \%$ LV $=95 \%$ luottamusväli

${ }^{4}$ p-arvo kuvaa eron merkitsevyyttä toimintarajoitteisten ja muun väestön välillä; ns. = ei tilastollisesti merkitsevä 
Toimintarajoitteiset kokivat myös muuta väestöä merkittävästi useammin, että koronaepidemia on vaikuttanut epäsuotuisasti terveyspalvelujen saantiin, sekä eläkeikäisten (Taulukko 2) että työikäisten ryhmässä (Taulukko 3). Kyselyä edeltävän vuoden aikana tarpeeseensa nähden riittämättömästi terveyspalveluita saaneiden osuus oli suurempi toimintarajoitteisilla kuin muulla väestöllä. Tyydyttymätöntä lääkärin vastaanottopalvelun tarvetta raportoi työikäisistä toimintarajoitteisista 41 prosenttia ja eläkeikäisistä 29 prosenttia, kun vastaava luku muussa väestössä oli noin 17 prosenttia kummassakin ikäryhmässä. Hoitajan palveluiden osalta noin kolmannes työikäisistä ja viidennes eläkeikäisistä toimintarajoitteisista henkilöistä ilmoitti, ettei ollut saanut niitä riittävästi tarpeisiinsa nähden, kun vastaava luku oli 12 prosenttia muussa väestössä. Hammaslääkärin palveluissa tyydyttymätön tarve korostui työikäisessä väestössä, jossa toimintarajoitteisista sitä oli lähes puolella ja muussa väestössä noin neljänneksellä.

Taulukko 3. Koronaepidemian koetut vaikutukset 21-66-vuotiaisiin toimintarajoitteisiin ja muihin ihmisiin koko väestössä ja ulkomaalaistaustaisessa väestössä. Ikä- ja sukupuolivakioitu.

\begin{tabular}{|c|c|c|c|c|c|c|c|c|}
\hline & \multicolumn{3}{|l|}{ Koko väestö } & \multicolumn{3}{|c|}{ Ulkomaalaistaustainen väestö } & \multirow[b]{2}{*}{$\mathrm{p}(\mathrm{CA})^{4}$} & \multirow[b]{2}{*}{$\mathrm{p}(\mathrm{DB})^{4}$} \\
\hline & $\begin{array}{l}{ }^{\mathrm{A}} \text { Toiminta- } \\
\text { rajoitteiset } \\
\%(95 \% \mathrm{LV})\end{array}$ & $\begin{array}{l}{ }^{\mathrm{B}} \text { Muu väestö } \\
\% \text { (95 \% LV) }\end{array}$ & $\mathrm{p}(\mathrm{AB})^{4}$ & $\begin{array}{l}{ }^{\mathrm{C}} \text { Toiminta- } \\
\text { rajoitteiset } \\
\%(95 \% \mathrm{LV})\end{array}$ & $\begin{array}{l}{ }^{\mathrm{D}} \text { Muu väestö } \\
\text { \% (95 \% LV) }\end{array}$ & $\mathrm{p}(\mathrm{CD})^{4}$ & & \\
\hline \multicolumn{9}{|l|}{ Arkielämä ja hyvinvointi } \\
\hline Yksinäisyys lisääntynyt ${ }^{1,3}$ & $\begin{array}{l}46,4 \\
(41,2-51,6)\end{array}$ & $\begin{array}{l}33,4 \\
(32,1-34,7)\end{array}$ & $<, 001$ & $\begin{array}{l}55,5 \\
(45,5-65,6)\end{array}$ & $\begin{array}{l}38,0 \\
(34,8-41,3)\end{array}$ & $<, 01$ & ns. & $<, 01$ \\
\hline $\begin{array}{l}\text { Yhteydenpito ystäviin ja } \\
\text { sukulaisiin vähentynyt }^{1,3}\end{array}$ & $\begin{array}{l}56,3 \\
(51,4-61,1)\end{array}$ & $\begin{array}{l}65,5 \\
(64,3-66,7)\end{array}$ & $<, 01$ & $\begin{array}{l}49,1 \\
(39,1-59,0)\end{array}$ & $\begin{array}{l}62,5 \\
(59,4-65,7)\end{array}$ & $<, 01$ & ns. & ns. \\
\hline $\begin{array}{l}\text { Kerho- tai yhdistystoi- } \\
\text { mintaan osallistuminen } \\
\text { vähentynyt }^{2}\end{array}$ & $\begin{array}{l}47,5 \\
(37,3-57,7)\end{array}$ & $\begin{array}{l}51,3 \\
(48,0-54,6)\end{array}$ & ns. & - & - & - & - & - \\
\hline 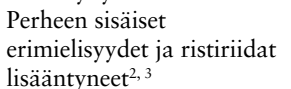 & $\begin{array}{l}14,9 \\
(8,0-21,8)\end{array}$ & $\begin{array}{l}15,0 \\
(13,0-17,0)\end{array}$ & ns. & $\begin{array}{l}27,9 \\
(18,1-37,7)\end{array}$ & $\begin{array}{l}17,0 \\
(14,4-19,6)\end{array}$ & $<, 05$ & $<, 05$ & ns. \\
\hline $\begin{array}{l}\text { Univaikeudet tai } \\
\text { painajaisunet } \\
\text { lisääntyneet }{ }^{1,3}\end{array}$ & $\begin{array}{l}26,5 \\
(21,5-31,4)\end{array}$ & $\begin{array}{l}10,1 \\
(9,3-10,9)\end{array}$ & $<, 001$ & $\begin{array}{l}42,7 \\
(32,7-52,8)\end{array}$ & $\begin{array}{l}21,0 \\
(17,9-24,1)\end{array}$ & $<, 001$ & $<, 01$ & $<, 001$ \\
\hline $\begin{array}{l}\text { Toiveikkuus tulevaisuuden } \\
\text { suhteen vähentynyt } t^{1,3}\end{array}$ & $\begin{array}{l}44,2 \\
(39,3-49,1)\end{array}$ & $\begin{array}{l}37,9 \\
(36,7-39,2)\end{array}$ & $<, 05$ & $\begin{array}{l}44,7 \\
(35,1-54,2)\end{array}$ & $\begin{array}{l}39,2 \\
(36,0-42,5)\end{array}$ & ns. & ns. & ns. \\
\hline 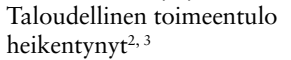 & $\begin{array}{l}28,0 \\
(21,1-34,9)\end{array}$ & $\begin{array}{l}18,2 \\
(16,3-20,2)\end{array}$ & $<, 01$ & $\begin{array}{l}61,9 \\
(52,5-71,3)\end{array}$ & $\begin{array}{l}40,5 \\
(37,4-43,6)\end{array}$ & $<, 001$ & $<, 001$ & $<, 001$ \\
\hline $\begin{array}{l}\text { Paljon huolta tartunnan } \\
\text { saamisesta }^{1,3}\end{array}$ & $\begin{array}{l}26,8 \\
(22,7-30,9)\end{array}$ & $\begin{array}{l}15,8 \\
(14,9-16,7)\end{array}$ & $<, 001$ & $\begin{array}{l}44,6 \\
(34,7-54,5)\end{array}$ & $\begin{array}{l}26,5 \\
(23,7-29,3)\end{array}$ & $<, 001$ & -5 & -5 \\
\hline $\begin{array}{l}\text { Paljon huolta terveyden- } \\
\text { huoltojärjestelmän } \\
\text { kyvystä hoitaa kaikki } \\
\text { koronapotilaat }^{1,3} \\
\text { Terveyspalvelut }\end{array}$ & $\begin{array}{l}28,8 \\
(24,4-33,2)\end{array}$ & $\begin{array}{l}18,1 \\
(17,2-19,1)\end{array}$ & $<, 001$ & $\begin{array}{l}46,2 \\
(36,2-56,2)\end{array}$ & $\begin{array}{l}27,0 \\
(24,2-29,8)\end{array}$ & $<, 001$ & -5 & -5 \\
\hline $\begin{array}{l}\text { Tyydyttämätön lääkärin } \\
\text { vastaanottopalvelun } \\
\text { tarve }^{1,3}\end{array}$ & $\begin{array}{l}41,0 \\
(35,7-46,3)\end{array}$ & $\begin{array}{l}17,6 \\
(16,4-18,8)\end{array}$ & $<, 001$ & $\begin{array}{l}34,0 \\
(22,3-45,7)\end{array}$ & $\begin{array}{l}22,7 \\
(18,7-26,7)\end{array}$ & ns. & ns. & $<, 05$ \\
\hline $\begin{array}{l}\text { Tyydyttämätön hoitajan } \\
\text { vastaanottopalvelun } \\
\text { tarve }^{1,3}\end{array}$ & $\begin{array}{l}30,9 \\
(25,4-36,4)\end{array}$ & $\begin{array}{l}12,0 \\
(10,8-13,1)\end{array}$ & $<, 001$ & $\begin{array}{l}32,8 \\
(19,7-46,0)\end{array}$ & $\begin{array}{l}16,6 \\
(12,8-20,5)\end{array}$ & $<, 01$ & ns. & $<, 05$ \\
\hline $\begin{array}{l}\text { Tyydyttämätön } \\
\text { hammaslääkäripalvelun } \\
\text { tarve }{ }^{1,3}\end{array}$ & $\begin{array}{l}46,3 \\
(40,4-52,3)\end{array}$ & $\begin{array}{l}24,6 \\
(23,1-26,0)\end{array}$ & $<, 001$ & $\begin{array}{l}44,8 \\
(31,9-57,6)\end{array}$ & $\begin{array}{l}29,5 \\
(25,0-34,0)\end{array}$ & $<, 05$ & ns. & $<, 05$ \\
\hline
\end{tabular}

${ }^{1}$ Tulos perustuu FinSote 2020 -aineistoon

${ }^{2}$ Tulos perustuu FinTerveys 2017 -seurantatutkimuksen aineistoon

${ }^{3}$ Tulos perustuu MigCOVID-aineistoon

${ }^{4} \mathrm{p}(\mathrm{AB}), \mathrm{p}(\mathrm{CD}), \mathrm{p}(\mathrm{CA}), \mathrm{p}(\mathrm{DB})$ : eron tilastollinen merkitsevyys neljän ryhmän $(\mathrm{A}, \mathrm{B}, \mathrm{C}$ ja $\mathrm{D})$ välillä; ns. = ei tilastollisesti merkitsevä

${ }^{5}$ Eron tilastollista testausta ei tehty vastausasteikkojen erilaisuuden vuoksi 


\section{VAIKUTUKSET ULKOMAILLA SYNTYNEILLÄ TYÖIKÄIIILLÄ TOIMINTARAJOITTEISILLA IHMISILLÄ}

Kuten koko työikäisessä väestössä, myös ulkomailla syntyneillä toimintarajoitteisilla ihmisillä monet koronaepidemian negatiiviset seuraukset olivat yleisempiä kuin muilla ihmisillä (Taulukko 3). Tämä tuli selvästi esiin yksinäisyydessä, univaikeuksissa, tartunnan saamiseen ja hoitoon liittyvissä huolissa, taloudellisessa toimeentulossa sekä riittämättömässä hoitajan ja hammaslääkäripalvelun saannissa. Koko väestössä toimintarajoitteisilla ihmisillä oli enemmän tyydyttymätöntä lääkärin hoidon tarvetta, mutta ulkomailla syntyneillä tämä ero ei ollut tilastollisesti merkitsevä. Koko väestöä tarkasteltaessa yhtä suuri osa työikäisistä toimintarajoitteisista ja muusta väestössä koki perheen sisäisten ristiriitojen lisääntyneen, mutta ulkomailla syntyneistä näin koki suurempi osa toimintarajoitteisista kuin muista ihmisistä.

Koronaepidemian vaikutukset olivat korostuneempia toimintarajoitteisilla ulkomailla syntyneillä työikäisillä verrattuna niihin, joilla oli vain jompikumpi näistä taustatekijöistä. Esimerkiksi taloudellisen tilanteensa koki heikentyneeksi 62 prosenttia toimintarajoitteisista ulkomailla syntyneistä ihmisistä, kun vastaava osuus oli 41 prosenttia muilla ulkomailla syntyneistä. Koko väestöä edustavassa aineistossa vastaavat luvut olivat 28 prosenttia toimintarajoitteisilla henkilöillä ja vain 18 prosenttia muulla väestöllä. Myös perheen sisäiset ristiriidat lisääntyivät korona-aikana erityisesti niiden ihmisten keskuudessa, jotka olivat sekä ulkomailla syntyneitä että toimintarajoitteisia. Heillä osuus oli 28 prosenttia, muilla ulkomailla syntyneillä 17 prosenttia ja vain toimintarajoite -ryhmällä 15 prosenttia. Myös univaikeudet lisääntyivät kaikkein eniten ulkomailla syntyneiden toimintarajoitteisten ihmisten ryhmässä.

\section{VAIKUTUKSET HENKILÖKOHTAISTA APUA KÄYTTÄVIEN VAMMAISTEN IHMISTEN ELÄMÄÄN}

Henkilökohtaisen avun kyselyyn vastanneista 21 vuotta täyttäneistä vammaisista ihmisistä 85 prosenttia oli toimintarajoitteisia tässä käytetyn määritelmän mukaisesti. Yleisimmin rajoitteita oli puolen kilometrin kävelyssä, jossa 75 prosenttia koki suuria vaikeuksia tai kykenemättömyyttä. Vastaavasti näkövaikeuksia oli 20:llä, kuulovaikeuksia kuudella ja muistiongelmia kymmenellä prosentilla vastaajista.
Henkilökohtaisen avun käyttäjillä monet koronaepidemian koetut vaikutukset olivat epäsuotuisampia kuin toimintarajoitteisilla ihmisillä väestöaineistossa (Kuvio 1). Yksinäisyyden lisääntyminen oli heillä yleisempää (51\%) kuin toimintarajoitteisten koko ryhmässä (45\%) ja muussa väestössä (33\%). Lähes joka kolmas henkilökohtaisen avun käyttäjä raportoi univaikeuksien lisääntyneen, kun toimintarajoitteisten koko ryhmästä näin raportoi lähes joka neljäs ja muusta väestöstä joka kymmenes. Toiveikkuus tulevaisuuden suhteen oli vähentynyt noin 40 prosentilla sekä henkilökohtaisen avun asiakkaista että kaikista toimintarajoitteisista henkilöistä, mutta hieman harvemmalla muussa väestössä (36\%). Yhteydenpito ystäviin ja sukulaisiin oli vähentynyt 68 prosentilla henkilökohtaisen avun ryhmässä ja 59 prosentilla toimintarajoitteisten koko ryhmässä.

Koronavirustartunnan saamisesta oli erittäin huolissaan suurempi osa henkilökohtaisen avun käyttäjistä $(37 \%)$ verrattuna koko toimintarajoitteisten ryhmään $(24 \%)$ ja muuhun väestöön (17 \%). Runsas neljännes (28\%) henkilökohtaisen avun käyttäjistä kantoi huolta terveydenhuoltojärjestelmän kyvystä hoitaa kaikki koronaviruspotilaat. Osuus oli samaa suuruusluokkaa koko toimintarajoitteisten ryhmässä, mutta selvästi suurempi kuin muussa väestössä (19\%).

Runsas kolmannes henkilökohtaista apua saavista vammaisista ihmisistä oli saanut tarpeeseensa nähden liian vähän fysioterapiaa (38 \%) ja sosiaalityöntekijän tai -ohjaajan palvelua (37 \%). Henkilökohtaisen avun saannin koki riittämättömäksi lähes neljännes $(24 \%)$ niistä, jotka sitä tarvitsivat.

Ongelmat henkilökohtaisen avun toteutuksessa korona-aikana olivat melko yleisiä. Niitä raportoi kolmannes (33\%) kyselyyn vastanneista ja heistä 70 prosenttia koki ongelmia olleen enemmän epidemian aikana kuin ennen sitä. Suurimpina pulmina mainittiin, että avustajia ei ollut saatavilla $(63 \%)$ tai avustaja oli sairaana tai karanteenissa $(61 \%)$. Runsas kolmannes vastaajista koki, että ei uskaltanut hankkia uutta avustajaa tai käyttää myönnettyjä tunteja (39\%). 


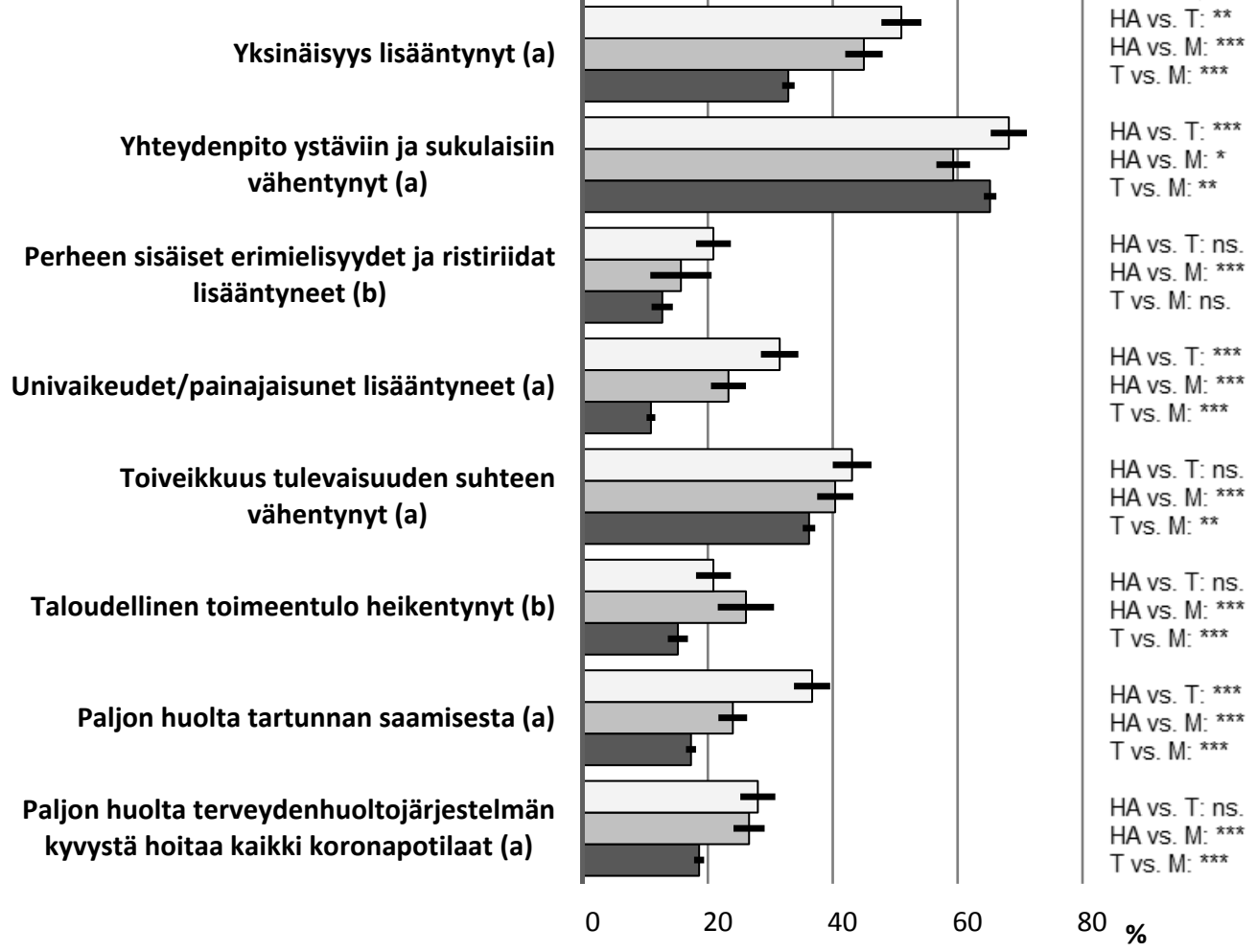

$\square H A=$ Henkilökohtaisen avun käyttäjät $\square T=$ Toimintarajoitteiset väestössä $\square M=$ Muu väestö

Kuvio1. Koronaepidemian koetut vaikutukset henkilökohtaista apua saavien, kaikkien toimintarajoitteisten henkilöiden ja muun väestön keskuudessa. 21 vuotta täyttäneet; ikä- ja sukupuolivakioitu.

(a) Tulokset perustuvat FinSote- ja Henkilökohtaisen avun saajien kyselyaineistoihin

(b) Tulokset perustuvat FinTerveys 2017 -seurantatutkimuksen ja Henkilökohtaisen avun saajien kyselytutkimuksen aineistoihin;

Tähdet kuvaavat eron tilastollista merkitsevyyttä: $\mathrm{p}<, 001^{* * *} ; \mathrm{p}<, 01^{* *} ; \mathrm{p}<, 05^{*} ;$ ns. = ero ei tilastollisesti merkitsevä;

$95 \% \mathrm{LV}=95 \%$ luottamusväli

\section{POHDINTA}

Tässä tutkimuksessa kuvaamme, miten toimintarajoitteinen väestö on keskimäärin selviytynyt korona-ajasta muuhun väestöön verrattuna. Nostamme lisäksi esiin, miten moninkertaiseen vähemmistöön kuuluminen lisää negatiivisten vaikutusten riskiä, kun tarkastelemme ulkomailla syntyneitä toimintarajoitteisia henkilöitä. Syvennämme havaintojamme tuloksilla vaikeavammaisten ihmisten kokemuksista korona-aikana. Tuloksemme perustuvat tuoreisiin tutkimusaineistoihin aiheesta, josta tutkittua tietoa on toistaiseksi niukasti (32-34).
Toimintarajoitteiset ihmiset olivat keskimäärin muita heikommassa asemassa jo ennen koronaepidemiaa, ja tuloksemme vahvistavat käsitystä siitä, että epidemia on lisännyt eriarvoisuutta yhteiskunnassamme. Toimintarajoitteiset aikuiset kokevat arjessaan ja hyvinvoinnissaan yleisemmin epidemian negatiivisia seurauksia, verrattuna henkilöihin, joiden toimintakyky on enintään lievästi rajoittunut. Lisäksi monet vaikutukset korostuvat vaikeavammaisilla henkilökohtaista apua käyttävillä ihmisillä sekä henkilöillä, joilla on toimintarajoitteen lisäksi ulkomaalaistausta. 
Univaikeudet, alhainen tulevaisuudenusko, yksinäisyys ja sosiaalinen eristäytyneisyys ovat yhteydessä psyykkiseen huonovointisuuteen ja heikompaan hyvinvointiin $(16,49,50)$. Nämä kokemukset ovat lisääntyneet väestössä korona-aikana $(51,52)$, ja tuloksemme osoittavat niiden korostuneen toimintarajoitteisilla ihmisillä, ja erityisen voimakkaasti henkilökohtaista apua käyttävillä vammaisilla henkilöillä. Tuloksemme saavat tukea Lebrasseurin ym. (53) katsauksesta, jossa havaittiin negatiivisten muutosten unessa ja mielialassa selvästi lisääntyneen fyysisesti toimintarajoitteisten ihmisten keskuudessa.

Negatiivisten psykososiaalisten seurausten taustalla vaikuttavat erilaiset epidemian rajoitustoimet sekä toimintatapojen muutokset toimintarajoitteisten ihmisten ympäristöissä. Moni vammainen henkilö koki jääneensä yksin, kun työntekijöiden käyntejä ja omaisten tapaamista asumisyksiköissä ja tukiasunnoissa rajoitettiin ja asukkaiden liikkumista kontrolloitiin tiukasti. Lisäksi päivä- ja työtoiminnan sulkeutumisen myötä monilta katosivat päivittäiset sosiaaliset kontaktit $(4,54$.) Omaehtoisen karanteenin noudattaminen, vierailukiellot vanhuspalveluyksiköissä ja kotikäyntien vähentäminen aiheuttivat sosiaalista eristäytymistä ikäihmisillä, joista merkittävällä osalla on heikentynyt toimintakyky $(52,55)$. Rajoitustoimet olivat riskiryhmien suojelemiseksi ja taudin rajaamiseksi välttämättömiä, mutta etenkin epidemian alkuvaiheessa ohjeistuksen epäselvyys ja tulkinnanvaraisuus johtivat liian tiukkoihin tai kategorisiin tulkintoihin esimerkiksi liikkumisen rajoittamisesta tai omaisten tai tukihenkilöiden tapaamisesta $(4,54,55)$. Kriisi yllätti monet vammaisten ja toimintarajoitteisten ihmisten kanssa toimivat tahot, eikä valmiuksia lieventää rajoitustoimien haittavaikutuksia heti ollut, mutta kokemusten kertyessä ja vältettävissä olevien epäkohtien paljastuessa uusia toimintatapoja ryhdyttiin aktiivisesti kehittämään ja toteuttamaan (54,55). Eri alueilta kertyneiden kokemusten - niin hyvien kuin huonojenkin - hyödyntäminen jatkossa ohjeistuksen kehittämiseksi on tärkeää, jotta toimintarajoitteisten ihmisten tarpeet tulisivat paremmin otettua huomioon. On myös varmistettava hyvä yhteistyö ja tiedonkulku terveydenhuollon ja sosiaalihuollon välillä, jotta päätöksiä tehdessä on riittävät tiedot epidemiasta ja sen torjuntatoimista.

Monelle toimintarajoitteiselle ihmiselle tois- ten ihmisten apu on välttämätöntä. Fyysisissä kontakteissa on olemassa mahdollisuus tartunnan saamiseen, ja etenkin epidemian alkuvaiheessa vallinneen suojavarustepulan vuoksi pelko tästä oli aiheellista. Drum ym. (56) raportoivat, että henkilökohtaista apua saavista vammaisista ihmisistä runsaalla puolella turvallisen etäisyyden pitäminen avustajaan ei onnistunut ja vajaalla neljänneksellä avun saanti keskeytyi. Tuloksemme osoittavat, että toimintarajoitteiset ihmiset kantoivat muita yleisemmin huolta tartunnan saamisesta. Henkilökohtaisen avun asiakkailla huoli oli kaikkein yleisintä. Tartunnan pelko on johtanut palveluiden käytön rajoittamiseen $(57,58)$, minkä seurauksena tyydyttymätön palvelutarve on voinut entisestään kasvaa. Epidemian yksi opetus tulevien kriisien varalta onkin riittävä suojavarusteiden saatavuus ja parempi kohdentaminen haavoittuvammassa asemassa olevien suojelemiseksi.

Myös huolet terveydenhuoltojärjestelmän kyvystä hoitaa kaikki potilaat olivat yleisempiä toimintarajoitteisten ihmisten keskuudessa kuin muilla. Tulosten mukaan riittämätön sosiaali- ja terveyspalvelujen saanti oli heillä yleisempää, mikä on sopusoinnussa muiden tutkimusten kanssa, joissa asiaa on kysytty toimintarajoitteisilta henkilöiltä tai heidän huoltajiltaan $(53,59)$. Sitä vastoin valtaosa Sosiaalibarometriin vastanneista sote-johtajista ja kolmannes sosiaalityöntekijöistä arvioi, että vammaispalveluita tarvitsevien palvelutarpeisiin pystyttiin vastaamaan hyvin. Vain 3-8 prosentin mielestä palvelutarpeisiin oli vastattu huonosti. Yli puolet sosiaalityöntekijöistä ei osannut arvioida tilannetta (3.)

Huolet tartunnan ja tarpeen mukaisen hoidon sekä riittävän tuen ja ohjauksen saamisesta aiheuttavat ylimääräistä stressiä ja ahdistusta $(28,60)$, ja ne kytkeytyvät eettisiin kysymyksiin terveyspalveluiden tasapuolisesta ja syrjimättömästä saatavuudesta pandemian kaltaisessa ylikuormitustilanteessa (61-65).

Perheen sisäisten erimielisyyksien ja ristiriitojen lisääntymistä havaittiin ikääntyneillä toimintarajoitteisilla muita samanikäisiä yleisemmin. Iäkkäiden kohtaaman kaltoinkohtelun riskitekijöitä ovat muun muassa heikko toimintakyky, toimintakykyä ja elämänhallintaa heikentävät sairaudet sekä korona-ajalle tyypilliset sosiaalisten kontaktien puute, yksinäisyys ja eristäytyminen $(66,67)$. 
Tutkimuksemme osoitti, että koronaepidemia heikensi taloudellista tilannetta toimintarajoitteisilla ihmisillä yleisemmin kuin muilla, mikä on voinut lisätä myös heidän kokemiensa huolten taakkaa. Myös Emersonin ym. (68) tutkimuksessa taloudelliset vaikutukset kohdistuivat toimintarajoitteisiin ihmisiin enemmän kuin muihin. Pandemiasta voi jäädä pitkäksi aikaa negatiivinen kasvujälki kansantalouteen (69), ja myös lama on uhkaamassa. Aiemmista taloudellisista lamoista tiedetään, että vakavat seuraukset kohdistuvat erityisesti haavoittuviin ryhmiin $(19,70,71)$, mukaan lukien kovenevat asenteet toimintarajoitteisia ihmisiä kohtaan (72).

\section{ULKOMAILLA SYNTYNEET TOIMINTARAJOITTEISET IHMISET - ERITYISEN HAAVOITTUVA RYHMÄ?}

Ulkomailla syntyneessä työikäisessä väestössä oli samankaltaisia eroja toimintarajoitteisten ja muiden henkilöiden välillä kuin koko väestössä. Jotkut epäsuotuisat vaikutukset korostuivat erityisesti ulkomailla syntyneillä toimintarajoitteisilla ihmisillä: univaikeudet, perheen sisäiset ristiriidat ja taloudellisen tilanteen heikentyminen. Myös huolet koronavirustartunnan saamisesta olivat ulkomailla syntyneillä toimintarajoitteisilla ihmisillä muita ulkomailla syntyneitä ja koko väestöä yleisempiä. Kuuluminen samanaikaisesti kahteen vähemmistöön, joissa molemmissa on epävarmuutta palveluiden saannista ja hoitoon pääsystä tai puutetta saavutettavasta pandemiaa koskevasta tiedosta, voi voimistaa stressiä ja syrjinnän pelkoa (28). Jos edellisten taustatekijöiden kanssa risteää vielä heikko taloudellinen tilanne, voi tällaiseen moninkertaiseen vähemmistöön kuuluminen moninkertaistaa myös pandemian negatiiviset vaikutukset mielialaan ja psyykkiseen hyvinvointiin.

Muita tutkimuksia, joissa koronaepidemian vaikutuksia olisi tarkasteltu ulkomaalaistaustaisessa toimintarajoitteisten ryhmässä, emme löytäneet. Sitä vastoin ulkomaalaistaustaisten tilanteesta on kertynyt joitain tietoja; esimerkiksi koronavirustartuntojen osuus on ollut suurempi kuin muussa väestössä (26). Lisäksi ulkomaalaistaustaisten henkilöiden keskuudessa on havaittu mielenterveyden heikentymistä, työpaikan menettämistä, syrjintäkokemuksia sekä lähisuhdeväkivallan lisääntymistä (73). Lisää tietoa toimintarajoitteen mukaisesti eriteltynä on jatkossa mahdollista saada tässäkin tutkimuksessa käytetystä MigCOVID-tutkimuksesta.

\section{MITEN TOIMINTARAJOITTEISTEN IHMISTEN OIKEUKSIEN TOTEUTUMISTA PANDEMIOISSA VOIDAAN EDISTÄÄ?}

Pandemian vaikutukset ovat kohdistuneet epäsuhtaisesti eri väestöryhmiin. Vaikka toimintaohjeistuksia ja suosituksia on annettu vähemmistöihin kuuluvien oikeuksien suojelemiseksi pandemioissa (74), on niiden noudattaminen lipsunut kriisitilanteissa monissa maissa $(34,63)$. YK:n vammaissopimuksen 11. artikla koskee vaaratilanteita ja humanitaarisia hätätilanteita, jonka kaltainen koronapandemiakin on (13). Se edellyttää sopimuksen osapuolien huolehtivan toimintarajoitteisten ihmisten turvasta ja suojelusta kaikin käytettävissä olevin keinoin. Tähänastiset kokemukset kentältä $(54,55)$ ja tutkimuksemme tulokset osoittavat, että tässä ei ole kokonaan onnistuttu. Suomessa on juuri julkaistu toinen YK:n vammaissopimuksen kansallinen toimintaohjelma (75), jossa erityistä huomiota saa myös turvallisuus poikkeusoloissa.

WHO ohjeistaa valtioita, kuntia, palveluntuottajia, toimintarajoitteisia ihmisiä itseään ja muuta väestöä, miten toimintarajoitteisuuden näkökulma tulisi ottaa huomioon koronapandemian vastaisessa taistelussa (6). Toimenpiteet koskevat muun muassa yhtäläistä ja esteetöntä hoitoon pääsyä, hoidossa tarvittavien välineiden tasapuolista jakoa, tarvittavan tuen antamista sekä riittävän ja ymmärrettävän informaation jakamista. Boyle ym. (33) nostavat esille puutteet tutkimustiedosta, jonka avulla voitaisiin tunnistaa toimintarajoitteisiin ihmisiin kohdistuvat epäsuhtaiset vaikutukset ja lieventää niitä. Esimerkiksi koronavirustartuntatilastoja tulisi voida tarkastella myös toimintarajoitteisuuden mukaan (63), minkä pitäisi Suomessa olla mahdollista. Kendall ym. (19) peräänkuuluttaa lisäksi yksityiskohtaisen, ajantasaiseen tietoon perustuvan toimintaohjeistuksen luomista hallinnon eri tasoille, jossa myös haavoittuvassa asemassa olevat vähemmistöryhmät huomioidaan (27). Suomessa näihin haasteisiin on tartuttu Kehitysvammaliiton, THL:n ja Kuntaliiton yhteishankkeessa, jossa tietoa epidemian ajalta kootaan monipuolisesti toimintarajoitteisilta ihmisiltä itseltään, palvelunjärjestäjiltä ja -tuottajilta sekä kuntien työntekijöiltä. Tiedon avulla kehitetään 
ohjeita ja toimintamalleja kuntatason poikkeusja kriisitilanteiden hoitoon. Hankkeen tavoitteena on tukea sekä vammaisten että ulkomaalaistaustaisten ihmisten selviytymistä ja toimintamahdollisuuksia.

\section{TUTKIMUKSEN VAHVUUDET JA RAJOITUKSET}

Tutkimuksessa käytettiin useita väestötutkimusaineistoja, joissa vastausaktiivisuus oli 47-60 prosenttia. Tiedonkeruu tapahtui sähköisillä ja paperilomakkeilla, jotka eivät olleet kaikille toimintarajoitteisten ryhmille saavutettavia. Tämä voi heikentää tutkimustulosten yleistettävyyttä. Toisaalta FinTerveys 2017 -seurantatutkimuksessa ja MigCOVID-tutkimuksessa pyrittiin tavoittelemaan puhelimitse niitä, jotka eivät toimintarajoitteen tai muun syyn vuoksi vastanneet aiempiin yhteydenottoihin. MigCOVID-tutkimuksessa puhelinhaastatteluita toteuttivat monikieliset haastattelijat ja tutkimusmateriaali oli monikielistä. Vastauskadon aiheuttamaa virhettä tuloksiin korjattiin painokertoimilla, mutta ei ole mahdollista arvioida, miten hyvin niillä onnistuttiin korjaamaan juuri toimintarajoitteisuudesta aiheutuvaa katoa.

Henkilökohtaista apua saavien kyselyyn vastanneet eivät välttämättä edusta hyvin koko henkilökohtaista apua saavien perusjoukkoa, koska rekistereistä ei yksilötason tietojen puuttuessa voida poimia otosta tästä ryhmästä. Suomessa vuonna 2019 henkilökohtaisen avun piirissä oli 25684 täysi-ikäistä henkilöä (31). Kyselyyn vastanneet olivat hieman nuorempia kuin koko perusjoukko. He saivat keskimäärin enemmän apua toimintarajoitteensa vuoksi verrattuna vammaispalveluita koskevaan kuntakyselyyn vuonna 2019 vastanneiden kuntien ilmoittamiin määriin (76). Kohderyhmää pyrittiin kuitenkin tavoittelemaan mahdollisimman hyvin jakamalla kyselyn sähköistä linkkiä kuntien ja niiden vammaispalveluiden vastuuhenkilöiden ja vammaisneuvostojen sekä vammaisjärjestöjen ja henkilökohtaista apua saavien työnantajaliiton kautta. Sähköiseen lomakkeeseen vastaaminen voi kuitenkin olla joillekin henkilöille vaikeaa tai mahdotonta, mikä saattaa heikentää aineiston edustavuutta.

Tutkimuksessa käytettiin toimintarajoitteisuuden kriteerinä kansainvälistä Washington
Groupin (14) suositukseen perustuvaa määritelmää, jossa yhdistetään erilaisia toimintakyvyn rajoitteita. Menettely sopii hyvin toimintarajoitteisten ihmisten tilanteen karkeaan kuvaamiseen, mutta toimintakyky on laaja-alainen ja monitasoinen ilmiö, jossa ei ole kyse vain dikotomiasta. Jatkoanalyyseissä toimintarajoitteisten ihmisten laaja ryhmä olisi hyvä jakaa yhtenäisempiin osaryhmiin aineistojen koon sallimissa rajoissa.

Tutkimuksen yksi vahvuus oli väestöä edustavat aineistot, jotka mahdollistavat toimintarajoitteisten ihmisten vertailun muuhun väestöön, tuottaen tietoa yhdenvertaisuudesta. Tutkimusaineistojen keruussa noudatettiin tutkimuseettisiä ohjeita kaikissa vaiheissa suunnittelusta ja tiedonkeruusta tutkimusaineistojen käsittelyyn.

\section{JATKOTUTKIMUKSIEN TARVE}

Tiedontarve toimintarajoitteisten ihmisten selviytymisestä koronapandemian aikana on suuri, ja kuvaileva tutkimuksemme vastaa siihen vain osittain. On tarpeen syventää tietoa erilaisia toimintarajoitteita kokevien sekä vaikeavammaisten ihmisten näkökulmasta ja selvittää, ovatko toimintarajoitteisten ja muiden ihmisten väliset erot hyvinvoinnissa ja palveluissa kärjistymässä pidemmällä aikavälillä. Lisätietoa tarvitaan myös siitä, mitkä tekijät suojaavat negatiivisilta vaikutuksilta tai altistavat niille toimintarajoitteisten ihmisten keskuudessa. Tarkastelua moninkertaisen vähemmistön näkökulmasta pitää jatkaa ja syventää. Tässä esitellyt tuoreet ja monipuoliset tutkimusaineistot antavat jatkotutkimuksille vahvan perustan.

\section{KIITOKSET:}

Kiitokset kaikille tutkimuksiin osallistuneille henkilöille.

\section{RAHOITTAJAT:}

Tutkimukseen on saatu valtion lisätalousarviossa Covid 19 -tutkimukseen osoitettua THL:n koordinoimaa rahoitusta sekä Euroopan Unionin ja Euroopan sosiaalirahaston myöntämää rahoitusta "Vammaisten ja ulkomaalaistaustaisten ihmisten selviäminen poikkeus- ja kriisitilanteissa - Tulevaisuutta luomassa covid-19-kokemusten pohjalta" -hankkeeseen. 
KIRJOITTAJIEN KONTRIBUUTIOT:

Sainio oli vastuussa käsikirjoituksen kirjoittamisesta ja Holm tilastollisista analyyseistä. Ikonen, Koponen, Korhonen, Nurmi-Koikkalainen, $\mathrm{Pa}-$ rikka, Skogberg, Väre, Sainio ja Koskinen osallistuivat tutkimusaineistojen suunnitteluun ja keräämiseen. Kaikki kirjoittajat osallistuivat tutkimuksen suunnitteluun ja käsikirjoituksen kommentointiin.

Sainio, P., Holm, M., Ikonen, J., Korhonen, M., Nurmi-Koikkalainen, P., Parikka, S., Skogberg, N., Väre, A., Koponen, P., Koskinen, S. Effects of the coronavirus pandemic and related restrictions on the lives of people with disabilities. Sosiaalilääketieteellinen aikakauslehti - Journal of Social Medicine 202 I: 58: 235-252.

Systematically collected data on how the restrictive measures to control the pandemic have affected people with disabilities are scarce. In this study, we describe the effects in the whole population, and in the population with a foreign background, disaggregated by disability, and on people receiving personal assistance.

The data come from three nationally representative population surveys conducted in the Finnish Institute for Health and Welfare: FinSote 2020, FinHealth 2017 follow-up, and the MigCOVID Survey on the foreign-born population. We also used data from a survey conducted among disabled people receiving personal assistance. The respondents completed questionnaires on the effects of the pandemic late in 2020 or early in 2021. Logistic regression analyses were conducted to assess the effects of the pandemic on the people with disabilities compared with the rest of the population. The results are presented as adjusted prevalences by age group.

During the epidemic, people with disabilities were more likely to report increased loneli- ness and sleep disturbances than the rest of the population. Also their financial situation had decreased more often. Worries of getting infected by the virus and inadequate availability of health services were more common among people with disabilities than among the others. Many of the negative consequences of the epidemic were particularly pronounced in disabled persons with a foreign background and in persons receiving personal assistance due to disability.

The pandemic may exacerbate inequalities of people with disabilities. The rights and needs of people with disabilities should be addressed more carefully in future crises. Instructions based on reliable data would help municipalities to promote equality.

Keywords: Functional limitations, disability, coronavirus epidemic, foreign background, equality

\footnotetext{
Saapunut (11.03.2021)

Hyväksytty (14.07.2021)
}

\section{LÄHTEET}

(1) Kestilä L, Härmä V, Rissanen P, toim. Covid19-epidemian vaikutukset hyvinvointiin, palvelujärjestelmään ja kansantalouteen. Asiantuntija-arvio, syksy 2020. Raportti 14/2020. Tampere: Terveyden ja hyvinvoinnin laitos; 2020. Luettu 25.2.2021. http://urn.fi/ URN:ISBN:978-952-343-578-0.

(2) Okonkwo NE, Aguwa UT, Jang M, ym. COVID-19 and the US response: accelerating health inequities. BMJ Evid Based Med 2020 Jun 3. Online ahead of print. doi:10.1136/bmjebm-2020-111426

(3) Sosiaalibarometri 2020. Anne Eronen, Heikki Hiilamo, Katja Ilmarinen, ym. Sosiaalibarometri. SOSTE Suomen sosiaali ja terveys, Helsinki 2020. Luettu 3.3.2021. https://www.soste.fi/ sosiaalibarometri/sosiaalibarometri-2020/

(4) Nurmi-Koikkalainen P, Hintsala S, Voutilainen M. Vammaisten henkilöiden hyvinvointi

ja palvelut. Teoksessa: Kestilä L, Härmä V, Rissanen P. (toim.) Covid-19-epidemian vaikutukset hyvinvointiin, palvelujärjestelmään ja kansantalouteen. Asiantuntija-arvio, syksy 2020. Raportti 14/2020. Tampere: Terveyden ja hyvinvoinnin laitos; 2020 , 125-129. Luettu 25.2.2021. http://urn.fi/ URN:ISBN:978-952-343-578-0.

(5) United Nations. Policy Brief: A DisabilityInclusive Response to COVID-19. 2020. Luettu 25.2.2021. https://unsdg.un.org/resources/policybrief-disability-inclusive-response-covid-19

(6) World Health Organization. Disability considerations during the COVID-19 outbreak. World Health Organization. Luettu 25.2.2021. https://apps.who.int/iris/handle/10665/332015.

(7) World Health Organization and World Bank. World report on disability. Geneva: World Health Organisation. 2011. 
(8) Sainio P, Sääksjärvi K, Nurmi-Koikkalainen $\mathrm{P}, \mathrm{ym}$. Toimintarajoitteisuuden yleisyys ja toimintarajoitteisten henkilöiden hyvinvointi tuloksia Terveys 2011 -tutkimuksesta. Teoksessa: Nurmi-Koikkalainen P, Ahola S, Gissler M, ym. Tietoa ja tietotarpeita vammaisuudesta. Analyysia THL:n tietotuotannosta. Työpaperi 38/2017. Helsinki: Terveyden ja hyvinvoinnin laitos;2017, 34-52. Luettu 25.2.2021. http://urn.fi/URN:ISBN:978-952-302-946-0

(9) Gissler M ja Sainio. Vammaisia on työikäisistä suomalaisista 7 tai 29 prosenttia. THL-blogi 10.3.2016. Luettu 25.2.2021. https://blogi.thl.fi/ vammaisia-on-tyoikaisista-suomalaisista7-tai-29prosenttia/

(10) WHO. Toimintakyvyn, toimintarajoitteiden ja terveyden kansainvälinen luokitus ICF. Helsinki; 2004.

http://urn.fi/URN:NBN:fi-fe201303252595

(11) Nurmi-Koikkalainen P: Vammaisuus käsitteenä ja ilmiönä. Teoksessa: NurmiKoikkalainen P, Ahola S, Gissler M, ym. Tietoa ja tietotarpeita vammaisuudesta. Analyysia THL:n tietotuotannosta. Työpaperi 38/2017. Helsinki: Terveyden ja hyvinvoinnin laitos;2017, 10-11. Luettu 25.2.2021. http://urn.fi/ URN:ISBN:978-952-302-946-0

(12) Era S, Tiilikainen E, Tarvainen M, ym. Vanhuuden ja vammaisuuden risteyksessä yhteistä kieltä etsimässä. Yhteiskuntapolitiikka 2020;85(4):437-442. Luettu 1.3.2021. http://urn.fi/URN:NBN:fi-fe2020091669800

(13) Vammaissopimus, SopS 26-27/2016. https:// finlex.fi/fi/sopimukset/sopsteksti/2016/20160027

(14) Washington Group: WG Short Set on Functioning. Luettu 1.3.2021. https://www. washingtongroup-disability.com/question-sets/ wg-short-set-on-functioning-wg-ss/.

(15) Kuper H ja Heydt P: The missing billion: access to health services for 1 billion people with disabilities. London School of Hygiene \& Tropical Medicine 2019. Luettu 2.3.2021. https://www.lshtm.ac.uk/TheMissingBillion

(16) Emerson E, Fortune N, Llewellyn G, ym. Loneliness, social support, social isolation and wellbeing among working age adults with and without disability: Cross-sectional study. Disability and health journal 2021;14(1):100965. doi: 10.1016/j.dhjo.2020.100965

(17) Sainio P, Parikka S, Pentala-Nikulainen O, ym. Toimintarajoitteisten ihmisten kokemuksia terveyspalveluista. Kirjassa: Kestilä L ja Karvonen S (toim.) Suomalaisten hyvinvointi 2018. Helsinki: Terveyden ja hyvinvoinnin laitos; 2019, 246-264. Luettu 1.3.2021. http://urn.fi/URN:ISBN:978-952-343-256-7

(18) Banks LM, Kuper H, Polack S. Poverty and disability in low- and middle-income countries: A systematic review. PLoS ONE 2017;12(12): e0189996. doi: 10.1371/journal.pone.0189996

(19) Kendall E, Ehrlich C, Chapman K, ym. Immediate and Long-Term Implications of the COVID-19 Pandemic for People
With Disabilities. Am J Public Health

2020;110(12):1774-1779.

doi: 10.2105/AJPH.2020.305890

(20) Armitage R, Nellums LB. The COVID-19 response must be disability inclusive. Lancet Public Health 2020 May;5(5):e257-1. Epub 2020 Mar 27.

doi: 10.1016/S2468-2667(20)30076-1

(21) Office for National Statistics. Updated estimates of coronavirus (COVID-19) related deaths by disability status, England: 24 January to 20

November 2020. 11 Feb 2021. Luettu 1.3.2021

https://www.ons.gov.uk/ peoplepopulationandcommunity/ birthsdeathsandmarriages/ deaths/ articles/ oronaviruscovid19 relateddeathsbydisabilitystatusenglandand wales/24januaryto20november2020.

(22) Henderson A, Fleming M, Cooper S, ym. COVID-19 infection and outcomes in a population-based cohort of 17,173 adults with intellectual disabilities compared with the general population. 2021. doi: 10.1101/2021.02.08.21250525

(23) Kuusio H, Seppänen A, Jokela S, ym. (toim.) Ulkomaalaistaustaisten terveys ja hyvinvointi Suomessa. FinMonik-tutkimus 2018-2019. Raportti 1/2020. Helsinki: Terveyden ja hyvinvoinnin laitos; 2019. Luettu 1.3.2021. http://urn.fi/URN:ISBN:978-952-343-034-1

(24) Castaneda A, Rask S, Koponen P, ym. (toim.) Maahanmuuttajien terveys ja hyvinvointi. Tutkimus venäläis-, somalialais- ja kurditaustaisista Suomessa. Raportti 61/2012. Tampere: Terveyden ja hyvinvoinnin laitos; 2012. Luettu 1.3.2021. http://urn.fi/URN:ISBN:978-952-245-739-4

(25) World Health Organization.

ApartTogetherSurvey. Preliminary overview of refugees and migrants self-reported impact of COVID-19. WHO, 2020. Luettu 1.3.2021. https://www.who.int/publications/i/ item/9789240017924

(26) Skogberg N, Hussein I, Castaneda A. Impact of Covid-19 human mobility restrictions on migrant origin population in Finland. Kirjassa: Sirkeci I, Cohen JH (toim.) COVID-19 and Migration: Understanding Pandemic and Human Mobility. Published: 11 November 2020 [Migration Series: 23]. Paperback: ISBN: 978-1-912997-59-6, Hardcover: ISBN: 978-1-912997-71-8, Digital: ISBN: 978-1-912997-60-2.

(27) Verduzco-Gutierrez M, Lara AM, Annaswamy TM. When Disparities and Disabilities Collide: Inequities during the COVID-19 Pandemic. Pm\&R 2020. Apr;13(4):412-414. doi: 10.1002/pmrj.12551

(28) Lund EM, Forber-Pratt AJ, Wilson C, ym. The COVID-19 pandemic, stress, and trauma in the disability community: A call to action. Rehabil Psychol 2020 Nov;65(4):313-322. doi: 10.1037/rep0000368

(29) Vammaispalveluiden käsikirja. Terveyden ja hyvinvoinnin laitos. Luettu 1.3.2021. https://thl.fi/fi/web/vammaispalvelujen-kasikirja 
(30) Laki vammaisuuden perusteella järjestettävistä palveluista ja tukitoimista 3.4.1987/380, $8 \mathrm{c} \mathbb{S}$ (19.12.2008/981). https://www.finlex.fi/fi/laki/ ajantasa/1987/19870380\#P8c

(31) Sotkanet-tietokanta. Terveyden ja hyvinvoinnin laitos, Helsinki, 2020. Luettu 1.3.2021. https://sotkanet.fi/sotkanet/fi/index

(32) Reed NS, Meeks LM, Swenor BK. Disability and COVID-19: who counts depends on who is counted. The Lancet Public Health 2020;5(8):e423.

doi: 10.1016/S2468-2667(20)30161-4

(33) Boyle CA, Fox MH, Havercamp SM, ym. The public health response to the COVID-19 pandemic for people with disabilities. Disabil Health J 2020 Jul;13(3):100943. doi: 10.1016/j.dhjo.2020.100943

(34) Martín-Cano MDC, Sampedro-Palacios $\mathrm{CB}$, Ricoy-Cano AJ, ym. Superdiversity and Disability: Social Changes for the Cohesion of Migrations in Europe. International journal of environmental research and public health 2020;17(18):6460. doi: 10.3390/ijerph17186460

(35) FinSote-tutkimus. Terveyden ja hyvinvoinnin laitos. Luettu 1.3.2021. https://thl.fi/fi/tutkimusja-kehittaminen/tutkimukset-ja-hankkeet/finsotetutkimus.

(36) Parikka S, Koskela T, Ikonen J, ym. Aikuisväestön hyvinvointi, terveys ja palvelut FinSote 2020 : Aikuisten palvelukokemuksissa ja hyvinvoinnissa alueellisia eroja. Tilastoraportti 16/2021. http://urn.fi/URN:NBN:fife2021052731871

(37) FinTerveys 2017 -seurantatutkimus. Terveyden ja hyvinvoinnin laitos. Luettu 1.3.2021. https:// thl.fi/fi/tutkimus-ja-kehittaminen/tutkimuksetja-hankkeet/kansallinen-finterveys-tutkimus/ finterveys-2017-seurantatutkimus

(38) Borodulin K ja Sääksjärvi K. (toim.) FinHealth 2017 Study - Methods. Raportti 17/2019. Terveyden ja hyvinvoinnin laitos, 2019. Luettu 15.2.2021. http://urn.fi/ URN:ISBN:978-952-343-449-3

(39) Koponen P, Borodulin K, Lundqvist A, ym. (toim.) Terveys, toimintakyky ja hyvinvointi Suomessa. Raportti 4/2018. Helsinki: Terveyden ja hyvinvoinnin laitos; 2018. Luettu 15.2.2021. http://urn.fi/URN:ISBN:978-952-343-105-8

(40) Koronaepidemian vaikutukset ulkomailla syntyneiden hyvinvointiin -tutkimus (MigCOVID). Terveyden ja hyvinvoinnin laitos. Luettu 1.3.2021. https://thl.fi/fi/tutkimusja-kehittaminen/tutkimukset-ja-hankkeet/ koronaepidemian-vaikutukset-ulkomaillasyntyneiden-hyvinvointiin-migcovid-

(41) Vammaisten henkilöiden kokemukset koronaepidemian aikana - kysely henkilökohtaisen avun käyttäjille. Terveyden ja hyvinvoinnin laitos. Luettu 1.3.2021. https:// thl.fi/fi/tutkimus-ja-kehittaminen/tutkimuksetja-hankkeet/vammaisten-henkiloidenkokemukset-koronaepidemian-aikana-kyselyhenkilokohtaisen-avun-kayttajille
(42) Berger N, Robine J. M, Ojima T, ym. Harmonising summary measures of population health using global survey instruments. Journal of Epidemiology and Community Health 2016;70:1039-1044. doi: 10.1136/jech-2015-206870

(43) Kreuter F, Valliant R. A survey on survey statistics: What is done and can be done in Stata. Stata Journal. 2007;7:1-21. doi: 10.1177/1536867X0700700101

(44) Seaman SR, White IR. Review of inverse probability weighting for dealing with missing data. Stat Methods Med Res. 2013;22:278-95. doi: 10.1177/0962280210395740

(45) Härkänen T, Karvanen J, Tolonen H, ym. Systematic handling of missing data in complex study designs-experiences from the Health 2000 and 2011 Surveys. J Appl Stat. 2016;43:277290.

doi: 10.1080/02664763.2016.1144725

(46) Long JS, Freese J. Regression models for categorical dependent variables using Stata (3rd ed.). College Station, TX: Stata Press; 2014.

(47) Williams R. Using the margins command to estimate and interpret adjusted predictions and marginal effects.Stata J. 2012;12:308-331. doi: 10.1177/1536867X1201200209

(48) Der G, Everitt, BS. A Handbook of Statistical Analyses Using SAS (3rd ed.). London, UK: Chapman \& Hall/CRC; 2008.

(49) Grandner M. Sleep, Health, and Society. Sleep Med Clin. 2017 March ; 12(1): 1-22. doi: 10.1016/j.jsmc.2016.10.012

(50) Saari J.(toim.) Yksinäisten Suomi. Gaudeamus: 2016.

(51) Suvisaari J, Lundqvist A, Linnaranta O, ym. Mieliala ja epidemiatilanteeseen liittyvät huolet. Teoksessa: Kestilä L, Härmä V, Rissanen P. (toim.) Covid-19-epidemian vaikutukset hyvinvointiin, palvelujärjestelmään ja kansantalouteen. Asiantuntija-arvio, syksy 2020. Raportti 14/2020. Tampere: Terveyden ja hyvinvoinnin laitos; 2020, 16-21. Luettu 1.3.2021. http://urn.fi/ URN:ISBN:978-952-343-578-0.

(52) Lehtisalo J, Palmer K, Mangialasche F, ym. Changes in lifestyle, behaviors, and risk factors for cognitive impairment in older persons during the first wave of the coronavirus disease 2019 pandemic in Finland: Results From the FINGER Study. Front. Psychiatry 2021;12:624125. doi: $10.3389 /$ fpsyt.2021.624125

(53) Lebrasseur A, Fortin-Bedard N, Lettre J, ym. Impact of COVID-19 on people with physical disabilities: A rapid review. Disability and Health Journal. doi: 10.1016/j.dhjo.2020.101014

(54) Tilannekatsaus valtioneuvostolle. Kehitysvammaliitto, Tukiliitto, FDUV, Autismiliitto, Vammaisperheyhdistys Jaatinen, 2020. Julkaisematon aineisto.

(55) Kehusmaa S, Hammar T, Borodulin K, ym. Iäkkäiden hyvinvointi ja palvelut. Teoksessa: 
Kestilä L, Härmä V, Rissanen P. (toim.)

Covid-19-epidemian vaikutukset hyvinvointiin, palvelujärjestelmään ja kansantalouteen. Asiantuntija-arvio, syksy 2020. Raportti 14/2020. Tampere: Terveyden ja hyvinvoinnin laitos; 2020, 119-124. Luettu 1.3.2021. http://urn.fi/URN:ISBN:978-952-343-578-0.

(56) Drum C, Oberg A, Cooper K, ym. COVID-19 \& Adults with Mobility Disabilities: Health and Health Care Access Online Survey Report. Rockville, MD: American Association on Health and Disability; 2020. Luettu 1.3.2021. https:// www.aahd.us/wp-content/uploads/2020/05/ COVID-19_Summary_Report.pdf

(57) Nurmi-Koikkalainen P, Korhonen M, Väre A. Vammaisten henkilöiden kokemuksia koronaepidemian ajalta - tuloksia henkilökohtaisen avun asiakaskyselystä. THL, Tutkimuksesta tiiviisti 24/2021. Luettu 30.6.2021. http://urn.fi/ URN:ISBN:978-952-343-657-2

(58) Sosiaalihuollon tilannekuvan viikkoseuraukset. Luettu 30.6.2021. https://thl.fi/fi/tutkimusja-kehittaminen/tutkimukset-ja-hankkeet/ koronaepidemian-sosiaaliset-vaikutuksetheikoimmassa-asemassa-oleviin-asiakkaisiinja-heidan-palveluihinsa/sosiaalihuollontilannekuvan-viikkoseuranta

(59) Jeste S, Hyde C, Distefano C, ym. Changes in access to educational and healthcare services for individuals with intellectual and developmental disabilities during COVID-19 restrictions. Journal of Intellectual Disability Research 2020 NOV;64(11):825-833. doi: 10.1111/jir.12776

(60) Umucu E, Lee B. Examining the impact of COVID-19 on stress and coping strategies in individuals with disabilities and chronic conditions. Rehabil Psychol 2020;65(3):193-198. doi: 10.1037/rep0000328

(61) Sabatello M, Burke TB, McDonald KE, ym. Disability, Ethics, and Health Care in the COVID-19 Pandemic. Am J Public Health 2020;110(10):1523-1527. doi: 10.2105/AJPH.2020.305837

(62) World Health Organization. Guidance for managing ethical issues in infectious disease outbreaks. World Health Organization; 2016. Luettu 1.3.2021. https:/apps.who.int/iris/handle/10665/250580

(63) Reichenberger V, Alburquerque, MDSV, David $\mathrm{RB}, \mathrm{ym}$. The challenge of including people with disabilities in the strategy to address the COVID-19 pandemic in Brazil. Epidemiol Serv Saude 2020 Nov 27;29(5):e2020770. doi: 10.1590/S1679-49742020000500023

(64) Haque OS, Stein MA. COVID-19 Clinical Bias, Persons with Disabilities, and Human Rights. Health Hum Rights 2020;22(2):285-290.

(65) Andrews EE, Ayers KB, Brown KS, ym. No body is expendable: Medical rationing and disability justice during the COVID-19 pandemic. Am Psychol 2020:No Pagination Specified. doi: 10.1037/amp0000709
(66) Santos MABD, Moreira RDS, Faccio PF, ym. Factors associated with elder abuse: a systematic review of the literature. Ciencia \& Saude Coletiva 2020;25(6):2153-2175. doi: 10.1590/1413-81232020256.25112018

(67) Lund E. Interpersonal Violence Against People With Disabilities: Additional Concerns and Considerations in the COVID-19 Pandemic. Rehabilitation Psychology 2020;65(3):199-205. doi: $10.1037 /$ rep0000347

(68) Emerson E, Stancliffe R, Hatton C, ym. The impact of disability on employment and financial security following the outbreak of the 2020 COVID-19 pandemic in the UK. J Public Health (Oxf) 2021 Jan 12. doi: 10.1093/pubmed/fdaa270

(69) Honkatukia J. Koronaepidemian ja rajoitustoimien vaikutukset kansantalouteen. Teoksessa: Kestilä L, Härmä V, Rissanen P. (toim.) Covid-19-epidemian vaikutukset hyvinvointiin, palvelujärjestelmään ja kansantalouteen. Asiantuntija-arvio, syksy 2020. Raportti 14/2020. Tampere: Terveyden ja hyvinvoinnin laitos; 2020, 145-150. Luettu 1.3.2021. http://urn.fi/ URN:ISBN:978-952-343-578-0.

(70) Whitehead M, Taylor-Robinson D, Barr B. Poverty, health, and covid-19. Yet again, poor families will be hardest hit by the pandemic's long economic fallout. BMJ 2021;372:n376 doi: 10.1136/bmj.n376

(71) Flynn S. Perspectives on austerity: the impact of the economic recession on intellectually disabled children. Disabil Soc. 2017;32(5):678-700. doi: 10.1080/09687599.2017.1310086

(72) Malli MA, Sams L, Forrester-Jones R, ym. Austerity and the lives of people with learning disabilities. A thematic synthesis of current literature. Disabil Soc. 2018;33(9):1412-1435. doi: 10.1080/09687599.2018.1497950

(73) Kivipelto M, Karjalainen P, Partanen A, ym. Sosiaalisesti vaikeassa tilanteessa olevien työikäisten hyvinvointi. Teoksessa: Kestilä L, Härmä V, Rissanen P. (toim.) Covid19-epidemian vaikutukset hyvinvointiin, palvelujärjestelmään ja kansantalouteen. Asiantuntija-arvio, syksy 2020. Raportti 14/2020. Tampere: Terveyden ja hyvinvoinnin laitos; 2020, 56-63. Luettu 1.3.2021. http://urn.fi/ URN:ISBN:978-952-343-578-0.

(74) World Health Organization. Guidance note on disability and emergency risk management for health. 2013. Luettu 1.3.2021. https://www. who.int/publications/i/item/guidance-note-ondisability-and-emergency-risk-management-forhealth

(75) Oikeus osallisuuteen ja yhdenvertaisuuteen. YK:n vammaisten henkilöiden oikeuksien yleissopimuksen kansallinen toimintaohjelma 2020-2023. STM:n julkaisuja 2021:2 Helsinki: Sosiaali- ja terveysministeriö; 2021. Luettu 1.3.2021. http://urn.fi/URN:ISBN:978-952-00-8459-2 
(76) Tanhua H. Vammaispalvelut 2019 - Kuntakyselyn osaraportti. Tilastoraportti 37/2020. Terveyden ja hyvinvoinnin laitos. Luettu 1.3.2021.

http://urn.fi/URN:NBN:fi-fe2020100878364

\section{PäIvi SAINIO}

$\mathrm{ft}$, TtM, erikoistutkija

Terveyden ja byvinvoinnin laitos

Väestönterveys

\section{Marja Holm}

FT, VTM, tutkija

Terveyden ja hyvinvoinnin laitos

Väestönterveys

\section{JONNA IKONEN}

FM, tilastotutkija

Terveyden ja hyvinvoinnin laitos

Väestönterveys

\section{MARIKA KORHONEN}

TtM, tutkija

Terveyden ja byvinvoinnin laitos

Hyvinvointivaltion tutkimus ja uudistaminen

\section{PäIVI NuRMi-KoIKKALAINEN}

esh, KM, johtava asiantuntija

Terveyden ja byvinvoinnin laitos

Hyvinvointivaltion tutkimus ja undistaminen

\section{SUVI PARIKKa}

VTM, kehittämispäällikkö

Terveyden ja hyvinvoinnin laitos

Väestönterveys

\section{Natalia Skogberg}

FT, tutkimuspäällikkö

Terveyden ja hyvinvoinnin laitos

Yhdenvertaisuus

\section{ANNA VärE}

TtM, tutkija

Terveyden ja byvinvoinnin laitos

Hyvinvointivaltion tutkimus ja undistaminen

\section{PäIVIKKI Koponen}

$T t T$, dosentti, johtava asiantuntija Terveyden ja hyvinvoinnin laitos Hyvinvointivaikuttajat

\section{SePpo Koskinen}

LT, VTM, tutkimusobjelmajohtaja Terveyden ja hyvinvoinnin laitos

Hyvinvointivaikuttajat 